\title{
Metode Tafsīr Bāț̣inī Syī’ah: Sebuah Telaah Kritis
}

\section{(The Method of Tafsīr Bātinī Syī’ah: A Critical Study)}

\author{
Muhammad Abdul Malik Al-Furqon ${ }^{1}$, Muhammad Taqiyuddin ${ }^{2}$ \\ ${ }^{1}$ Ma'had Aly Darusy Syahadah Boyolali, ${ }^{2}$ Universitas Darussalam Gontor \\ 1'muhammadabdulmalikalfurqon123@gmail.com, ${ }^{2}$ taqiyuddin@unida.gontor.ac.id
}

DOI: $10.29240 /$ alquds.v4i2.1703

Submitted: 2019-06-20 | Revised: 2020-09-03 | Accepted: 2020-09-11

\begin{abstract}
Given the urgency that the Bātinī’s Tafsir (interpretation) itself is classified by some scholars as the Sufistic model of Isyārī's interpretation which puts forward metaphorical exegesis, thus, its position is controversial and needs to be explained. In fact, Bātinin's interpretation is widely used by the Shi'ah school. The methodology of Bātinin’s interpretation in Syı̀ah is identical to their aqīdah. This study, using the literature research model, involved an object in the form of Syì ah literature simply referred to as an authoritative source; especially from the Islamic scholars who are mu'tabar. The data were analyzed descriptively and in a comparative analysis following a critical analysis of the empirical literature; namely the narrative model. Thus, the narrative of Bātinī Shî̀ah's interpretation model was revealed, to be juxtaposed with several Tafsīr works having been rooted in the Sunni tradition as a relevant source to explain the position of Bāținì's interpretation and the ideological influence surrounding and underlying its emergence. This study found that the Bātinin's interpretation was identical to the transition of the meaning of the verse al-Qur'ān from its zāair to its bāțin; by highlighting several specific patterns oriented towards strengthening one of the pillars of the Shīah teachings itself, namely the imāmah.
\end{abstract}

Keywords: Science of Tafsīr; Tafsīr Bāṭinī; Syì ah; Imāmah

\begin{abstract}
Abstrak. Mengingat urgensi bahwa Tafsīr Bāṭin̄̄ sendiri digolongkan oleh sebagian ulama sebagai Tafsir Isyārī model sufistik yang mengedepankan penjelasan metaforis. Sehingga, posisinya menjadi kontroversial dan perlu dijelaskan. Padahal, Tafsīr Bāṭinī digunakan secara luas oleh aliran Syì’ah. Metodologi Tafsīr Bāṭinī dalam Syìah identik dengan aqīdah mereka. Kajian dengan model Penelitian Pustaka ini, melibatkan obyek berupa literatur Syīah yang cukup disebut sebagai sumber otoritatif; khususnya dari kitab ulama Sy’’ah yang mu'tabar. Data dianalisa secara deskriptif dan analisa komparatif berikut analisa kritis atas literatur empiris (critical analysis of empirical literature); yakni model naratif. Sehingga, model Tafsir Bāṭinī Syìah diungkap narasinya, untuk disandingkan dengan beberapa karya tafsīr yang telah mengakar pada tradisi Sunni
\end{abstract}


sebagai sumber yang revelan untuk menjelaskan posisi Tafsīr Bāținī dan pengaruh ideologi yang melingkupi serta mendasari kemunculannya. Kajian ini menemukan, bahwa Tafsīr Bāținī identik dengan peralihan makna ayat al-Qur’ān dari zāhirnya kepada bāținnya; dengan menyoroti beberapa pola khusus yang berorientasi pada penguatan salah rukun dari ajaran Syìah itu sendiri: yakni imāmah.

Kata Kunci: Ilmu Tafsīr; Tafsīr Bāṭin̄i; Syīah; Imāmah

\section{Pendahuluan}

Al-Qur'ān adalah sumber hukum Islām paling utama. Ia merupakan wahyu yang secara murni makna dan lafalnya dari Allāh SWT. ${ }^{1}$ Walau demikian, tidak semua lafal atau ayat di dalamnya dapat dipahami secara langsung oleh para hamba. Ada ayat-ayat yang membutuhkan bayān (penjelasan). Oleh karenanya, Allāh mengutus seorang Nabī untuk menjelaskan secara sempurna isi dari alQur'ān. Penjelasan dari Nabī tersebut, kemudian ditangkap oleh para sahabatnya dan disampaikan secara turun-temurun kepada generasi setelahnya. ${ }^{2}$ Dengan demikian, tidak ada satu bagian pun dari al-Qur'ān melainkan sudah ada penjelasannya dari Nabī Muhammad SAW. dan para Salaf al-Sălih. . ${ }^{3}$ Penjelasan inilah yang kemudian disebut sebagai tafsir al-Qur'ān.

Tafsīr al-Qur'ān merupakan ilmu yang sangat digemari oleh para ulama. Banyaknya kitab-kitab tafsir klasik yang ada saat ini adalah bukti antusias mereka dalam mempelajari dan mendokumentasikan ilmu tersebut. Selain itu, mereka juga menetapkan dan menyepakati metode-metode dalam penafsiran. Apabila ditelisik lebih dalam, pada hakikatnya metode-metode tersebut adalah intisari dari riwayat-riwayat tafsir yang datang dari Nabī SAW. dan para sahabatnya. Hal ini mereka lakukan adalah tidak lain untuk menjaga al-Qur'ān dari pemaknaanpemaknaan yang tidak tepat atau menyimpang. ${ }^{4}$

Seiring berjalannya waktu, muncullah firqab-firqab yang melakukan penafsiran al-Qur'ān secara mandiri. Salah satunya adalah Syìah, firqah yang mengaku bagian dari Islām. ${ }^{5}$ Mereka membedakan diri dari metode tafsir-tafsir

${ }^{1}$ Mannā’ Khalīl Al-Qațān, Mabāhiš Fì 'Ulüm Al-Qưr'ān (Madīnah: Dār al-Ma’ārif li anNashr wa al-Tauzî, 2000) p. 22.

2 'Alī Ahmad Al-Sālūs, Ma'a Al-Syżah Al-Iśnà 'Ashariyah Fì Al-'Ușül Wa Al-Furü' (Cairo: Maktabah Dār al-Qur'ān, 2003) vol. 2, p. 458.

${ }^{3}$ Jalāluddin Al-Suyūțī, Al-Itqān Fì 'Ulūm Al-Qur'ān (Riyāọ: Dār al-Hijrah li al-Nashr wa al-Tauzì, 1996) vol. 1, p. 86.

${ }^{4}$ Muhammad Husain Al-Żahabī, Al-Tafsì Wa Al-Mufassirūn (Cairo: Maktabah Wahbah, 2003) vol. 1, p. 104-105.

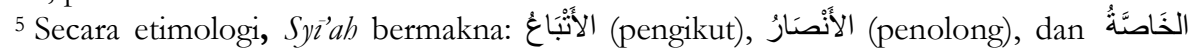
(teman dekat). Adapun secara terminology, Syî̀ah adalah setiap kelompok yang mengutamakan 'Alī bin Abī Tâlib dari para kehalîfah sebelumnya, dan mereka berpendapat bahwa Ahlulbait adalah 
ulama Sunnī, bahkan metode-metode penafsiran yang telah disepakati para Salaf sebelumnya. Syı̀ah memiliki metode tersendiri dalam menafsirkan al-Qur'ān, yaitu metode Tafsīr Bāținī. Hal ini berawal dari doktrin keyakinan mereka bahwa al-Qur'ān memiliki makna tersirat (bätịin) dan makna tersurat (z̧āhir). ${ }^{6}$ Manusia secara umum hanya dapat mengetahui makna zähbir-nya saja, sementara makna bătinì hanya diketahui oleh para imām dan orang-orang yang mereka kehendaki. ${ }^{7}$ Dengan demikian, Syìah dapat secara bebas manafsirkan setiap ayat, hingga akhirnya berdampak pada pembentukan 'aqìdah dan sharỉab Syïah yang cenderung berbeda dengan Ablussunnah.

Kajian ini didasari atas beberapa penelitian yang menjadikan tafsir sebagai obyek yang menarik untuk dikaji aspek ideologisnya. Secara khusus, kajian seperti ini telah dilakukan oleh Musolli yang menyoroti perbedaan makna Abl al-Bayt dalam Syīah dan Sunni pada surat al-Ahzāb ayat 33; yang menemukan bahwa pembatasan tafsir Syìah tentang makna Abl al-Bayt cenderung dipengaruhi oleh salah satu ide Syìah bahwa Abl al-Bayt hanya

orang yang paling berhak menjadi khalifah. Lihat: Ahmad bin Muhammad Al-Muqrī, Al-Mișbäh Al-Munir (Madīnah: al-Maktabah al-'Ashriyah, 2008) vol. 5, p. 134; Mușțafā bin Muhammad, Shubhatur Räfị̣ah Haula Al-Șabābah (Beirut: Daar al-Kutub al-'Ilmiyyah (DKI) Publisher, 2000) vol. 1, p. 95; Syìah pertama kali muncul adalah pasca perang Șiffin. Saat itu terjadi perundingan anatar pihak 'Alī dengan Mu'āwiyah, atau yang disebut dengan peristiwa al-Tạ̣kim (arbitrasi). Namun hasil dari perundingan tersebut ternyata mendatangkan permasalahan baru setelah diumumkan kepada kedua belah pihak. Sekelompok orang yang semula berpihak kepada 'Alī, pergi memisahkan diri dan berkumpul di Naḥrawain, mereka inilah yang disebut sebagai golongan Khawārij. Sementara sebagian besarnya lagi tetap bersama dan menjadi pembela setianya, maka disebutlah mereka itu sebagi Syīah 'Alī (Pengikut 'Alī). Dengan demikian, Syī'ah 'Alī yang muncul pertama kali, sejatinya adalah para pengikut setia khalífah (saat berselisih ijtihād dengan Mu'āwiyah) dan hanya bersifat kultural. Lihat: Ihsān Ilahi Zāahir, Al-Syìa Wa AlTashayyu' (Pakistan: Idārah Tarjūman al-Sunnah, 1984) p. 25; 'Alī Muhammad Al-Șalabī, Sìrah Amirul Mukminin 'Alì Bin Abì Tälib (Beirut: Daar al-Fikr, 2005) vol. 12, p. 270; Namun, seiring berjalannya waktu, penyimpangan-penyimpangan mulai muncul oleh gerakan Saba'iyah yang bersembunyi di dalam kelompok 'Alī. Dengan tetap menyandang nama Syīah, mereka memisahkan diri dari para pendukung 'Alī yang berakidah lurus. Kelompok inilah yang kemudian hari terpecah menjadi beberapa sekte sesat dan menyimpang dari Islām. Lihat: Abū Bakar bin Al-'Arabī, Al-'Awāșim Min Al-Qawāșim (Cairo: Maktabah Dār al-Turās, 1999) p. 348350; Nașir Al-Qifārī, Ușūl Madžhab Al-Syż̀ah Al Imāmiyah Al-Iśnā 'Ashariyah (Riyāọ: Mamlakah al-'Arabiyah al-Su'ūdiyah, 2007) vol. 1, 57-69.

${ }^{6}$ Muhammad Ya'qūb Al-Kulainī, Ușūl Al-Kâfî̀ (Beirut: Dār al-Ta’ārif al-Mațbu'āt, 1990) vol. 1, p. 374; Al-Żahabī, Al-Tafsì Wa Al-Mufassirün vol. 2, p. 22-23.

${ }^{7}$ Muhammad Bāqir Al-Majlisī, Bịhārul Anwār (Beirut: Daar al-Kutub al-'Ilmiyyah (DKI) Publisher, 2000) vol. 7, p. 302; Al-Qifārī, Ușūl Madžbab Al-Syīảh Al Imāmiyah Al-Iśnā 'Ashariyah vol. 1, p. 176. 
sebatas $A$ shï al-Kisā. ${ }^{8}$ Ahmad Zainal Abidin pun turut menemukan bahwa tafsir Sy’’ah telah memiliki tren yang membedakan dirinya dengan tafsir model Sunni; hal ini disimpulkan secara khusus dari kajiannya atas Tafsīr al-Qummi yang cenderung beroposisi secara politis kepada Bani Umayyah pada masa itu. Hal yang diketahui, bahwa al-Qummi dalam tafsirnya cenderung mengunggulkannya untuk memaknai beberapa ayat guna menjustifikasi konsep imämah sebagai salah satu rukun ajaran Syı̉ah. ${ }^{9}$

Karya serupa dengan obyek yang berbeda, dapat kita telaah dari kajian Fiddian Khairuddin dan Amaruddin. Mereka menggunakan karya Tabataba’i dalam melacak pengaruh ideologis sistem aqidah Tafsir al-Mì̃än Syìah yang berupa imāmah, mut'ah, dan lainnya. ${ }^{10}$ Hal ini sebagaimana dikaji oleh Reza Aram, yang menulis tentang perbedaan pemaknaan terma mustaqarr dan mustawda'. Yang mana, ia menganalisa bahwa tiap corak tafsir memproyeksikan dimensi ideologis pada produk tafsirannya. ${ }^{11}$

Sedangkan karya yang secara tematis menyoroti metodologi tafsir secara umum dapat kita mengerti dari tulisan Ali Suleiman Ali. Kajiannya, secara fokus membahas dan mengklarifikasi beberapa jenis metodologi penafsiran serta corak ideologis yang mendasarinya. ${ }^{12}$ Selain itu, terdapat pula kajian mengenai tren perkembangan tafsir al-Qur'ān, yang sama-sama menyoroti aspek metodologisnya; dengan mengambil sampel di Indonesia dan Iran. Namun karya ini lebih fokus pada hal-hal yang mendasari tren tersebut; misalnya latar belakang dan atmosfer hawzah dan kajian filsafat di Iran, juga beberapa tafsir yang muncul dan ditulis mengadaptasi beberapa bahasa lokal untuk memudahkan dalam mempelajarinya. Hal ini memperjelas perbedaan ideologis antara tafsir tersebut. ${ }^{13}$

Berbagai karya di atas, telah berkontribusi dalam menjelaskan pokok ideologis dalam metodologi Tafsīr Syì ah itu sendiri. Hanya saja, dalam beberapa

${ }^{8}$ Musolli Musolli, “Ahlul Bayt Perspektif Syiah Dan Sunni: Studi Tafsir Al-Mizan Dan Tafsir Tahrir Wa Al-Tanwir," AT-TURAS: Jurnal Studi Keislaman 4, no. 1 (2017): 69-79.

${ }^{9}$ Ahmad Zainal Abidin, "Shi'ite Ideology Bias in Al-Qummi Tafsir: Study of Ali Imran and Al-Nisa' Chapters," ESENSLA: Jurnal Ilmu-Ilmu Ushuluddin 19, no. 2 (2018): 185-97.

${ }^{10}$ Fiddian Khairuddin and Amaruddin, "MENGUNGKAP PENAFSIRAN ALQUR'AN VERSI SYIAH Kajian Tafsir Al-Mizan Fi Tafsir Al-Qur'an Karya at-Tabataba'i," SYAHADAH 6, no. 2 (2018): 92-114.

${ }^{11}$ Mohammad Reza Aram, "The Classical Tafsir Works Of Both Shias And Sunnis On The Interpretation of The Mustaqarr And Mustawda," European Journal of Science and Theology 11, no. 4 (2015): 13-22.

12 Ali Suleiman Ali, Books-in-Brief: A Brief Introduction to Qur'anic Exegesis (International Institute of Islamic Thought (IIIT), 2018).

${ }^{13}$ Muhammad Iqbal and Ja'far Ja'far, “Contemporary Development Of Qur'anic Exegesis In Indonesia And Iran," Journal of Contemporary Islam and Muslim Societies, 2019, https://doi.org/10.30821/jcims.v3i1.4144. 
karya di atas masih memerlukan klarifikasi, baik dari segi kajian literatur yang lebih luas, hingga beberapa contoh produk penafsiran Syì'ah yang memproyeksikan ideologi imämah sebagai asumsi dasar atasnya. Selain itu, kebanyakan karya yang menyoroti Tafsīr Bāținī belum banyak mengklarifikasi produk tafsīr tersebut; kecuali hanya aspek ideologi imāmah yang mendasarinya. Sehingga, kajian yang memuat klarifikasi atas perbedaan Tafsīr Bāținī (Isyārî) Sunni dan Syìah dapat diposisikan secara jelas; berikut corak tafsīr Sufistik yang telah diulas secara sederhana di atas.

Lebih lanjut lagi, masih perlu adanya penjelasan bagaimana klarifikasi Tafsīr Sunni atas beberapa Tafsīr Bāținī tersebut; khususnya pada ayat yang cenderung disebut sebagai pendukung ajaran imämah yang merupakan salah satu inti pokok dari ajaran Syỉah. Artikel ini berusaha mengulas Tafsīr Bāținī secara mendasar, dan pengaruh ideologi imämah dalam penafsiran para ulama mu'tabar Sy'̈'ah tersebut, melalui analisa komparatif berikut analisa kritis atas literatur empiris (critical analysis of empirical literature); yakni model naratif. Metode analisa ini mengungkap secara naratif berbagai contoh ayat yang ditafsirkan secara Bätini ala Syżah, dan membandingkannya dengan Tafsīr Sunnī sebagai sumber yang revelan untuk menjelaskan posisi Tafsīr Bāṭin̄̄ Syìah dalam perhelatan Tafsir bi al-Ra'yi secara umum.

\section{Pembahasan}

\section{Kontroversi Tafsīr Bāṭinī}

Tafsīr Bāṭinī dianggap kontroversi; karena seringkali tercampur dengan pemahaman, bahwa tafsir tersebut merupakan bagian dari Tafsìr Isyārī. Di mana Tafsīr Isyārī adalah model khas sufistik, yang kebanyakan menjelaskan ayat melalui statemen yang seringkali metaforis lagi membutuhkan penjelasan atas makna tersebut. Beberapa tafsir Sufî seperti milik Ibn Arabī, al-Tustūrī, al-Amalī, dan lainnya cenderung diposisikan sebagai tafsir yang menekankan makna bätin dari ayat; sebagai ganti dari makna lahirnya. ${ }^{14}$

Pada tahapan selanjutnya, berbagai aliran melakukan klaim bahwa metode Tafsir Bāṭinī mereka merupakan bagian integral dari tafsir bercorak sufistik seperti milik Ibn Arabi contohnya; menimbulkan kesalahfahaman bagi

${ }^{14}$ Izzul Madid, "Tafsir Sufi: Kajian Atas Konsep Tafsir Dengan Pendekatan Sufi," Wasathiyah 2, no. 1 (2018); Niila Khoiru Amaliya, “Arah Metodologi Tafsir Kontemporer," QALAMUNA: Jurnal Pendidikan, Sosial, Dan Agama 10, no. 01 (2018); Muhammad Farid Abdullah, “المعنى الظاهر والمعنى الباطن عند الحسين النهبي في التفسير والمفسورن," LIS ANLA: Journal of Arabic Education and Literature 1, no. 1 (2017): 74-90. 
beberapa fuqohā. ${ }^{15}$ Sehingga, mempersulit dan memperkeruh usaha demarkatif antara aliran dalam Islam yang merupakan Sunn̄ atau lainnya. Belum lagi, ilmu tafsir sangat berpengaruh terhadap pembentukan hukum maupun pola ibadah dan keyakinan suatu aliran dalam Islam. ${ }^{16}$

Dari latar belakang inilah, Imam Ghazalī melakukan beberapa klasifikasi atas tafsir yang 'tercampur' antara Isyārì maupun Bätinī; yang sesuai dengan teologi Sunni. ${ }^{17}$ Berikut pula klasifikasi, bahwa metode penafsiran tersebut memiliki berkesuaian dengan perkembangan keilmuan; khususnya ilmu syariat yang telah baku dalam berbagai madzhab Sunni. ${ }^{18}$ Mengingat, model Tafsir Isyārī dan Bāțin̄i adalah bagian dari Tafsìr bil Ra'yi. Sehingga, muncullah istilah tafsir bil-ra'yi al mamdūh dan al-madzmum. ${ }^{19}$ Untuk melihat lebih detail tentang Tafsīr Bāṭin̄i dan pengaruh ideologis di baliknya, kita mengambil sampel dari Tafsīr Bāțin̄̄ yang dikenal luas dalam tradisi keilmuan Syìah.

\section{Tafsīr Bāṭin̄̄ Menurut Syī’ah}

\section{Definisi Tafs̄ir Bāṭin̄̄}

Secara bahasa, lafal bạtini adalah șifat isim fa il yang berasal dari kata bațana-yabtunu, yang berarti sesuatu yang tidak nampak atau tersembunyi. ${ }^{20}$ Dalam al-Qur'ān, terdapat beberapa ayat yang menyebutkan lafal tersebut, diantaranya: "Dan tinggalkeanlah dosa yang nampak dan yang tersembunyi." 21 Apabila lafal bätinì diawali dengan tafsir, maka susunan dua kata tersebut menjadi istilah tersendiri yang memiliki arti khusus. Dikatakan Tafsīr Bāținī maka maknanya adalah metode penafsiran dengan mendahulukan makna yang tersembunyi (bātini) dari makna tersuratnya (zāhir) dengan merujuk kepada pendapat orang-

${ }^{15}$ Sansan Ziaul Haq, "Hermeneutika Sufistik: Telaah Epistemologi Takwil Ibn 'Arabi," At-Tibyan: Jurnal Ilmu Alqur'an Dan Tafsir 4, no. 1 (2019): 1-25; Muhammad Hasanil Asy'ari, "Menyingkap Tabir Dibalik Efistemologi Irfani. Doc," Jurnal Penelitian Tarbawi: Pendidikan Islam Dan Isu-Isu Sosial 3, no. 1 (2018): 9-20.

${ }^{16}$ Abdul Muaz and Tri Budi Prasetyo, "Mendaras Relasi Zikir Dan Jiwa," An-Nufus 1, no. 1 (2019): 27-51; Qays Abdullah Muhammed, “لالنفسير الإثاري بين الروعة والبدعة)" Journal of Divinity Faculty of Hitit University 13, no. 25 (2014).

${ }^{17}$ Zulkifli Mohd Yusoff et al., "Fi Munasabat Suwar Al-Quran Al-Karim," Journal of Qur'anic Studies 11, no. 1 (2015): 215, https://doi.org/10.22067/naqhs.v48i1.32876; Sulaiman Sulaiman, "Tafsir Ilmi Dalam Persfektif Al-Qur'an," Al-Bayan: Jurnal Ilmu Al-Qur'an Dan Hadist 2, no. 2 (2019): 164-75.

${ }^{18}$ Muhammad Arsad, "Pendekatan Dalam Tafsir (Tafsir Bi Al Matsur, Tafsir Bi Al Rayi, Tafsir Bi Al Isyari)," Yurisprudentia: Jurnal Hukum Ekonomi 4, no. 2 (2018): 147-65.

${ }^{19}$ Ozi Setiadi, "Faktor-Faktor Penyebab Penyimpangan Dalam Tafsir," Al-Tadabbur: Jurnal Ilmu Al-Qur'an Dan Tafsir 3, No. 01 (2018).

${ }^{20}$ Umar Ahmad Mukhtar Abdul Hamid, Mu'jam Al-Lughah Al-Arabiyah Al-Mu'äshirah (Lexicon of the Modern Arabic Language), vol. 2 p. (Cairo: Alam Al-Kutub, 2008) vol. 1, p. 220.

21 “QS. Al-An'ām: 120," n.d. 
orang yang ma'șim. ${ }^{22}$ Metode ini adalah metode yang kerap digunakan oleh firqah-firqah seperti: al-Mulāḥidah, al-Qarāmițah, al-Bāṭiniyah, Syì̄ah dan lain-lain.

\section{Eksistensi Makna Bāṭin̄i dan Ẓāhir}

Kaum Sy’’ah sendiri meyakini bahwa al-Qur'ān mempunyai makna tersirat (bätini i) dan tersurat (zähirir). ${ }^{23}$ Manusia biasa secara umum hanya dapat mengetahui makna zähir-nya saja, sementara makna bätinì hanya diketahui oleh para imām dan orang-orang yang mereka kehendaki. ${ }^{24}$ Keterangan dan riwayat tentang hal ini telah banyak tercantum dalam kitab-kitab induk dan tafsir mereka. Muhammad bin Mas'ūd al-Samarqandī, dalam tafsirnya mencantumkan sebuah riwayat yang cukup masyhur. Dari Jābir al-Ja'fî, ia berkata,

"Aku bertanya kepada Abü Ja'far tentang permasalahan tafsir al-Qur'än dan ia menjawabnya. Kemudian aku bertanya lagi untuk yang kedua dan ia menjawabnya dengan jawaban berbeda. Lantas aku bertanya kenapa demikian, padabal engkau telah menjawabnya dengan selain ini sebelumnya." Abü Ja'far berkata kepadaku: "Wahai Jäbir, sesunggubnya dalam al-Qur'än terdapat makna implisit yang di dalamnya terkandung makna bäțini dan zähir; dan juga makna eksplisit yang di dalamnya terkandung makna zāhir.,"25

Al-Kulainī dalam muqadimah Ușūl al-Käfi-nya menegaskan bahwa Allāh telah memberikan petunjuk kepada para imām dari Ahlulbait tentang agama-

${ }^{22}$ Muhammad Zarghani and Muhammad Hassan Nadem, "The Authority of the Shiite Imams'(AS) Tradition as the Qur'anic Interpreter and Its Relationship with the Authority of the Quran's Appearances," Asian Journal of Research in Social Sciences and Humanities 6, no. 6 (2016): 2381-93.

${ }^{23}$ Muhammad bin al-Hasan Al-'Āmilī, Al-Fașl Al-Mubimmah Fī Ușūl Al-Aimmah (Qom, Iran: Mu'assasah Ma'ārif Islāmī, 1998) vol. 2, p. 195; Seyyed Abdullah Esfahani and Seyyede Masoome Hosseini, "Comparative Analysis of 'Nature of Interpretation by Qur'an Judgment' from Shia and Sunni Commentators' Perspective," Journal of History Culture and Art Research 6, no. 3 (2017): 1199-1207.

${ }^{24}$ Al-Majlisī, Biḥārul Anwàr vol. 7, p. 302; Al-Qifārī, Ușūl Maď̌hab Al-Shīah Al Imāmiyah Al-Iśnā 'Ashariyah vol. 1, p. 176; Ahmad Fauzan, "MANHAJ TAFSIR AL-Mizan Fi Tafsir Al-Qur'an Karya Muhammad Husain Tabataba'i," Al-Tadabbur: Jurnal Ilmu Al-Qur'an Dan Tafsir 3, no. 02 (2018): 117-36.

${ }^{25}$ Muhammad bin Mas'ūd bin 'Tyāshī Al-Samarqandī, Tafsìr Al-'Tyāshì (Bağdād: alMaktabah al-'Ilmiyah al-Islāmiyah, 1994) vol. 1, p. 11; Sayid Al-Ṭabațaba'1̄, Al-Mìzàn Fì Tafsìr AlQur'ān (Qom, Iran: Manshurat Mu`assasah al-A ’lami li al-Mathbu'at, 1997) vol. 3, p. 73. Teksnya adalah sebagai berikut:

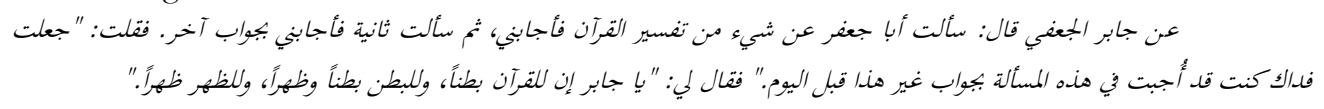


Nya. ${ }^{26}$ Dan diantara petunjuk tersebut, Ia telah menyingkap hijāa mengenai Tafsīr Bāṭinī dari zāahir ayat-ayat al-Qur'ān yang sebelumnya tidak diketahui oleh hamba. $^{27}$

Sayid Hāshim al-Baḥrānī menyebutkan sebuah riwayat dalam tafsīr alBurhān-nya, dari Muhammad bin Manșūr, ia bertanya kepada seorang hamba yang șälih mengenai firman Allāh: "Katakanlah: 'Tuhanku hanya mengharamkan perbuatan yang keji, baik yang nampak atau pun yang tersembunyi... "I menjawab,

"Sesunggubnya al-Qur'än memiliki makna tersurat (zähir) dan tersirat (bātinì), setiap perkara yang Alläh haramkan menunjukkan makna zähir, sedangkan makna bätini-nya adalah para imām yang fäjï. Dan setiap perkara yang Allāh halalkan menunjuke.en makna zähir, sedangkan makna bätini-nya adalah para imäm (Syïab) yang hak. "28

Apabila melihat pada literatur Ahlussunnah, tidak dipungkiri bahwa sebagian mufassir Sunnī juga membenarkan adanya makna zāhir (tersurat) dan ishāri (tersirat) dalam al-Qur'ān. Tetapi berbeda dari mereka, ${ }^{29}$ kelompok Syı̀’ah melampaui teoritisasi Sunnī dan mengklaim bahwa makna zāhir al-Qur'ān di sisi Allāh adalah dakwah kepada tauhīd, kenabian dan risālah. ${ }^{30}$ Sedangkan makna bāṭin̄i-nya adalah seruan kepada wilāyah imāmah Ahlulbait. ${ }^{31}$ Dengan demikian,

${ }^{26}$ Al-Kulainī, Ușūl Al-Käfì vol. 1, p. 25.

${ }^{27}$ Al-Kulainī vol. 1, p. 4; Sajjad H Rizvi, “'Only the Imam Knows Best' The Maktab-e Tafkik's Attack on the Legitimacy of Philosophy in Iran," Journal of the Royal Asiatic Society 22, no. 3-4 (2012): 487-503.

${ }^{28}$ Al-Kulainī, Ușūl Al-Käfì vol. 1, p. 374; Sayid Hāshim Al-Baḥrānī, Al-Burbān Fì Tafsìr Al-Qur'än (Qom, Iran: Manshurat Mu`assasah al-A lami li al-Mathbu'at, 2006) vol. 5, p. 285. teks aslinya sebagai berikut:

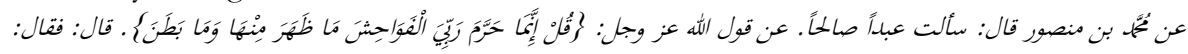

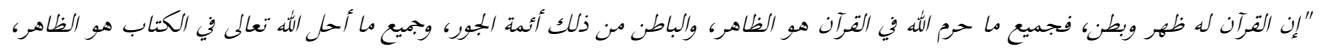

$$
\begin{aligned}
& \text { والباطن من ذلك أئمة الحق." }
\end{aligned}
$$

${ }^{29}$ Dalam Ahlussunnah, penafsiran al-Qur'ān dengan melihat kepada makna tersiratnya disebut metode ishärì. Sekilas, metode ini seolah sama dengan tafsīr bāținī Syīah, namun pada hakikatnya terdapat perbedaan yang cukup signifikan. Para ulama Salaf telah menetapkan beberapa ḍawābit (ketentuan) pada metode ishārì yang tidak dipakai dalam tafsīr bāținī Syì̄ah. Lihat: As-Sayid Mukhtār, Manhaj Al-Tafsìr Baina as-Sunnah Wa as-Shi ah Al-Imāmiyah Al-Iśnā 'Ashariyah (Riyāụ: Shabkah Mishkāt al-Islāmiyah, 1997) vol. 1, p. 124-128.

30 Al-Żahabī, Al-Tafsì Wa Al-Mufassirün vol. 2, p. 22-23.

${ }^{31}$ Alī Al-Mashkinī, Isthilahāt Al-Ușl Wa Mu'ẓam Abhasỉha (Qom, Iran: Duftur Nashr alHādī, 1951) p. 146. 
jelaslah bahwa dibalik seruan Syīah kepada Tafsīr Bāținī adalah untuk mendoktrin seseorang agar menerima ideologi mereka. ${ }^{32}$

Selain melakukan penafsiran ayat dengan cara bāținī, Syì'ah juga sebelumnya telah menyatakan bahwa al-Qur'ān yang ada di tangan manusia telah mengalami tahrif pasca wafatnya $\mathrm{Nab}^{-33}$ Sebenarnya, metode penafsiran bāṭin̄ dan tuduhan mereka terhadap tahrif al-Qur'ān, hanyalah alasan yang sengaja dirancang untuk dapat menyelamatkan dan menutupi celah pada doktrin inti mereka, yaitu imämah. Hal ini berawal dari kenyataan bahwa apa yang mereka serukan ternyata tidak didapati satu naș pun yang secara eksplisit menjelaskannya. Sehingga, sebagai dalihnya mereka hanya bisa berargumen dengan dalil-dalil yang tersira ${ }^{34}$ sekaligus mengatakan bahwa ayat tentang imamah telah dihapus oleh orang-orang yang memusuhi Ahlulbait (versi Syỉah). ${ }^{35}$ Dengan demikian, Tafsīr Bāținī dan taḥrif al-Qur'ān adalah bentuk kebohongan dan tuduhan keji mereka terhadap para sahabat. ${ }^{36}$

32 Secara umum, naș yang ditafsirkan oleh Sỷ’ah secara bāṭini adalah ayat-ayat yang digunakan untuk melegalkan atau menguatkan setiap perkara ușūl dan furū' dalam ideologi mereka. Adapun selain itu, ada beberapa yang mereka sebenarnya me-naql dari tafsīr-tafsīr Sunni, seperti yang dilakukan oleh Abū Ja'far Muhammad bin al-Hasan al-Ṭusī dan al-Faḍl bin al-Hasan al-Ṭabrāsī. Lihat: Ahmad bin Abdul Halīm bin Taimiyah, Minḥäj Al-Sunnah Al-Nabawiyah (Cairo: Mu'assasah Qurțūbah, 1984) vol. 3, p. 246.

${ }^{33}$ Menurut Syīah, al-Qur'ān telah mengalami taḥrif ketika 'Uṡmān membukukannya menjadi sebuah muṣhaf. Para sahabat pasca wafatnya Nabī dengan sengaja membuang banyak ayat dan surat, terutama yang berisi tentang keutamaan-keutamaan Ahlulbait dan keburukalkeburukan para penentangnya. Lihat: Al-Kulainī, Ușūl Al-Käfí vol. 1, p. 374.

34 Muhammad Riọā Al-Muẓaffar, 'Aqāid Al-Imāmiyah (Beirut: Dār al-Ta'ārif alMațbu'āt, 1991) p. 63-65.

35 Al-Kulainī dalam al-Käfı̀ meriwayatkan, dari Ja’far al-Șādiq bahwa al-Qur'ān yang dibawa turun oleh Jibrīl kepada Muhammad SAW. berjumlah 17.000 ayat, sedangkan yang ada saat ini hanya berkisar enam ribu sekian ayat. Sisanya tersimpan di kalangan Ahlulbait dari

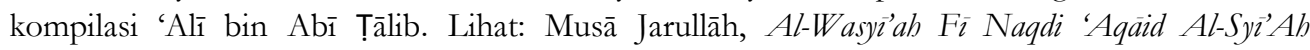
(Pakistan: Sahīl Akadimī Lahūr, 1983) p. 23.

36 Tuduhan Syìah terhadap tahrîf al-Qur'ān adalah sesuatu yang mengada-ada. Hal tersebut bertentangan dengan banyak fakta yang diantaranya adalah dari Ahlulbait sendiri. Terbukti, bahwa 'Alī bin Abī Ṭālib yang disanjung dan diagungkan kaum Syīah sebagai sayyidul aimmah (penghulunya para imām), adalah salah satu sahabat yang hafal al-Qur'ān pada masa Nabī SAW. Di samping itu, beliau juga dikenal sebagai salah satu juru tulis wahyu. Bahkan, ia juga termasuk sahabat Nabī yang menyepakati mușḥaf 'Uśmānī. Ibnu Abī Dāwud (w. 316 H) meriwayatkan, ketika khalīfah 'Uṡmān bin 'Affān R.a. membakar muṣḥaf-muṣhaf selain muṣhaf imàm, 'Alī bin Abī Ṭālib R.a. mengatakan: "Seandainya 'Uśmān belum melakukan hal itu, niscaya aku yang akan melakukan.” Lihat: Abdullāh bin Sulaimān Al-Sajistānī, Al-Mașabif (Makkah: Dār al-Bashāir al-Islāmiyah, 2002) vol. 1, p.12. 
Apabila ditelisik lebih dalam, penafsiran secara bāṭinī pertama kali dipromosikan oleh kelompok Saba'iyah, pengikut Abdullāh bin Saba'. ${ }^{37}$ Yaitu, ketika mereka berupaya mencari sandaran dari al-Qur'ān untuk mendukung kepercayaan tentang al-raj'ah (hidup kembali setelah mati). ${ }^{38}$ Ibnu Saba' mengatakan: "Sungguh mengherankan orang-orang yang percaya bahwa Isa putra Maryam akan kembali ke dunia tetapi tidak percaya Muhammad akan kembali, ${ }^{39}$ padahal Allāh SWT. berfirman: "Sesunggubnya yang mewajibkean atasmu (melaksanakan bukum-bukum) al-Qur'än, benar-benar akan mengembalikan kamu ke tempat kembali." 40 Dengan demikian, dapat dinyatakan bahwa metode yang digunakan Syì'ah dalam penafsiran bukanlah berasal dari Islam.

\section{Syarat Mufassir}

Sebagaimana telah masyhur dalam doktrin Syì ah, bahwa kedudukan para imām adalah laksana Nabī, baik dari sisi ke-ma'ṣum-an, sifat serta ilmunya. Atas dasar ini, mereka meyakini bahwa hanya para imām yang paling mengetahui tentang al-Qur'ān dan berhak menafsirkannya. Bahkan, mereka samapai mengisyaratkan pada al-Qur'ān dan imām dengan sebuah ungkapan: "Itu adalah al-Qur'ān yang diam (maksudnya al-Qur'ān yang ditulis dalam mușhaf), sedangkan itu adalah al-Qur'ān yang berbicara (maksudnya para imām)." ${ }^{41}$ Dengan demikian, dalam pandangan Sy'̈ah syarat mufassir haruslah seorang imām sebab mereka adalah representasi al-Qur'ān yang dapat berbicara.

${ }^{37}$ Muhammad bin Jarīr al-Ṭabarī, Tarikh Al-Ṭabarì (Madīnah: Maktabah al-Ma'ārf li anNashr wa al-Tauz $\overrightarrow{1}, 1979)$ vol. 5, p. 374.

38 'Alī bin Muhammad Al-Faqihī, Diräsah 'an Al-Firāq Fì Tärikh Al-Muslimīn (Madīnah: al-Jami`ah al-Islāmiyah, 1995) p. 233-234.

${ }^{39}$ Muhammad Rị̣ā An-Najafí, Al-Syīả Wa Ar-Raj'ah (Bag̀dād: Maṭba’ah al-Adāb alAshrāf, 1990) p. 19.

${ }^{40}$ QS. Al-Qașash: 85, ayat ini disalahtafsirkan oleh Syỉah bahwa Rasulullāh SAW. akan kembali lagi ke dunia setelah ia wafat. Padahal, maksud "tempat kembali" pada ayat tersebut adalah kembali kepada Allāh setelah kematian. Lihat: Jalāluddin Al-Suyūțīi, Al-Dur Al-Manś̄̄r (Beirut: Daar al-Fikr, 1993) vol. 6, p. 446.

${ }^{41}$ Zāhir, Al-Shìah Wa Al-Tashayyu' p. 45; Mereka juga berpendapat bahwa imām Ja’far al-Șādiq juga berpendapat: "Sesungguhnya al-Qur'ān tidak berbicara dan tidak dapat diajak berbicara.” Dan bahwa ayahnya, al-Bāqir mengatakan: "Al-Qur'ān telah menuliskan tamsil-tamsil untuk manusia, dan dia telah berbicara pada Nabī-Nya dengan al-Qur'ān itu dan juga pada kami, maka tidak ada yang tahu selain kami. 'Alī bin Ibrāhīm Al-Qummī, Tafsìr Al-Qummì (Beirut: Mu assasah al-A’lā lil Mațbu'at, 1973) p. 2, 293, dan 425; Mereka mengatakan bahwa imām 'Alī mengatakan: "Itulah al-Qur'ān, mintalah ia untuk berbicara padamu, tidak mungkin dia akan berbicara. Aku akan memberitahukan pada kalian. Sesungguhnya di dalamnya ada ilmu yang telah lalu dan ilmu yang akan datang hingga Hari Kiamat. Dia akan menghakimi urusan diantara kalian dan menerangkan hal-hal dimana kamu sekalian berselisih tentang hal tersebut. Dan andai kata kalian menanyakan padaku tentang hal tersebut, maka akan aku beri tahu padamu, karena akulah yang layak mengajari kalian.” lihat: Al-Kulainī, Ușūl Al-Käfì vol. 8, p. 50. dan vol. 1, p. 61 
Al-Kulain̄̄ (w. 328 H) ${ }^{42}$ dalam Ușūl al-Kāfì-nya ${ }^{43}$ mengatakan: "AlQur'ān hanya dapat dijadikan hujjah jika ada qayyim (pengawas/supervisor). Dan 'Alī adalah pengawas/supervisor dari al-Qur'ān itu, menaatinya adalah wajib, ia menjadi hüjjah terhadap manusia setelah Rasūlullāh." ${ }^{44}$ Al-Kulainī kemudian menguatkan pendapatnya dengan menyebutkan sebuah riwayat yang cukup panjang dari Abū Abdillāh Ja'far al-Ṣādiq, ${ }^{45}$ ia mengatakan,

"Cukuplah manusia berdalil dengan al-Qur'än. Andaikan mereka menemukan seorang penafsir, maka sesunggubnya Rasülulläh $S A W$. telab menafsirkannya kepada satu orang. Kemudian orang itu menafsirkannya kepada para imàm. Dan dia itu adalah 'Ali bin Abi Tälib.',46

Senada dengan Șabibul Kāfì, Muhammad Bāqir al-Majlisī (w. $1110 \mathrm{H})^{47}$ juga menyebutkan sebuah riwayat dalam Biḥärul Anwār-nya bahwa Abū Ja'far Muhammad al-Jawwād (w. $220 \mathrm{H}$ ) ${ }^{48}$ bertanya: "Wahai Qatādah, apakah engkau adalah ahli fikihnya penduduk Bașrah?” Qatādah menjwab: "Demikianlah menurut mereka." Abū Ja'far bertanya lagi: "Telah sampai berita kepadaku bahwa engkau menafsirkan al-Qur'ān?" "Benar," jawab Qatādah. Ia berkata:

${ }^{42}$ Muhammad Ya'qūb al-Kulainī adalah penulis kitāb hadis̉ paling mashhur, al-Käfì dan termasuk sebagai ahli hadis ternama di kalangan Syì ah.

${ }^{43}$ Kitab yang oleh Syìah dipandang sebanding dengan kitab Șạ̣ị al-Bukhärì bagi Ahlussunnah. Lihat: Al-Qifārī, Ușūl Madžhab Al-Shìah Al Imāmiyah Al-Iśnà 'Ashariyah vol. 1, p. 55.

${ }^{44}$ Al-Kulainī, Ușūl Al-Käfì vol. 1, p. 188; Muhammad bin al-Hasan Al-Ṭūsī, Rijäl AlKäshì (Qom, Iran: Mu `assasah an-Nashr al-Islāmi al-Tabi ah li Jama’ah al-Mudarrisīn, 2007) p. 41; Ibnu Babāwaih Al-Qummī, Tlal Al-Shara'İ (Najef: Manshurāt al-Maktabah al-Haidāriyah wa Mațba'uha, 1966) p. 192; Ahmad bin Muhammad Al-Barqī, Al-Mahāsin (Qom, Iran: al-Majma' al-'Alāmī li Ahlilbait, 2014) p. 268. teks aslinya sebagai berikut:

$$
\text { "أن القرآن لا يكون حجة إلا بقّمِم، وإن عليا كان قيم القرآن وكانت طاعته مغترضة، وكان الحجة على الناس بعل رسول الله." }
$$

${ }^{45}$ Nama lengkapnya adalah Abū Abdillāh Ja'far bin Muhammad bin 'Alī bin Husain bin 'Alī al-Șādiq. Ia merupakan imām Syì’ah yang ke-6, ahli ilmu agama dan ahli hukum Islām (fiqih). Aturan-aturan yang dikeluarkannya menjadi dasar utama bagi mazhab Ja'fari atau Dua Belas imām.

${ }^{46}$ Al-Kulainīi, Ușūl Al-Käfì vol. 1, p. 25.

${ }^{47}$ Ia bernama Muhammad Bāqir bin Muhammad Taqī al-Majlisī, lahir pada tahun 1037 H di kota Isfahan. Ia hidup pada masa Daulah Șafawiyah di Qum, yang secara resmi bermadzhab Sy’’ah imāmiyah. Al-Majlis̄i dikenal sebagai ulama daulah yang banyak menulis kitab-kitab Syïah, salah satu karangannya yang sangat terkenal dan menjadi rujukkan Syïah hingga masa sekarang adalah Biḥärul Anwàr. Ia wafat pada tahun $1110 \mathrm{H}$.

${ }^{48}$ Ia adalah Abū Ja'far Muhammad bin 'Alī al-Jawwād, imām Syì’ah yang ke-9. 
"Celaka engkau wahai Qatādah, yang mengetahui isi al-Qur'ān hanyalah orang yang diajak bicara (oleh Allāh, yaitu para imām Syìah)!"49

Terkait hal ini, terdapat pula sebuah Hadīis yang sangat masyhur di kalangan Syì'ah, al-'Āmilī (w. $1104 \mathrm{H})^{50}$ meriwayatkannya dalam Wasä'il al-Syż'ah dan Ibnu Babāwaih al-Qummī (w. $381 \mathrm{H})^{51}$ dalam Āmalì al-Sadūq, bahwa Rasūlullāh SAW. bersabda: "Sesungguhnya Allāh telah menurunkan kepadaku al-Qur'ān. Barangsiapa menyimpang darinya maka akan tersesat. Dan barangsiapa mencari ilmunya pada selain "Alī maka akan binasa.",52

Berdasarkan riwayat dan penjelasan di atas, maka dapat disimpulkan bahwa Syī'ah meyakini al-Qur'ān tidak bisa dijadikan huijah kecuali dengan adanya qayyim yang tidak lain adalah salah satu dari dua belas imām. ${ }^{53}$ Maka pada realisasinya, mereka pun menolak setiap tafsir yang tidak bernasab kepada Ahlulbait, sekalipun itu dari sahabat-sahabat Nabi. ${ }^{54}$ Apabila kita mengkaji riwayat-riwayat tersebut berdasarkan al-Qur'ān dan Sunnah. Sungguh pernyataan yang merupakan keyakinan mereka itu tidaklah dapat diterima dan sangat bertentangan dengan dalil, baik naqli maupun 'aqlì. Berikut bantahan dan bukti kesesatannya:

49 Al-Majlisī, Bịhārul Anwār vol. 2, p. 237; Al-Qifārī, Ușūl Madžhab Al-Shīah Al Imāmiyah Al-Iśnà 'Ashariyah vol. 1, p. 163.

${ }^{50}$ Muhammad bin al-Hasan al-'Āmilī atau yang mashhur dengan sebutan al-Hur al'Āmilī adalah seorang mubaddis ternama yang hidup di masa Daulah Șafawiyah.

${ }^{51}$ Ia adalah Abū Ja'far Muhammad bin 'Alī bin al-Hasan Ibnu Babāwaih al-Qummī, seorang mufassir ternama Syı̈ah abad ke-5 Hijriah.

52 Muhammad bin al-Hasan Al-'Āmilī, Wasā́lil Al-Syżăh (Qom, Iran: Mu'assasah Alilbait lil Ihyā̄ al-Turāś, 1992) vol. 18, p. 131; Ibnu Babāwaih Al-Qummī, Āmalì Al-Ṣadūq (Qom, Iran: Manshurat Mu`assasah al-A lami li al-Mathbu'at, 2009) p. 40; teks aslinya sebagai berikut:

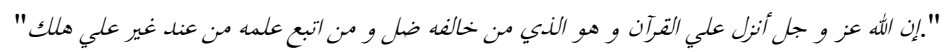

Keterangan: Riwayat ini adalah maudu' (palsu). Tidak satupun dari sahabat yang meriwayatkannya. Ia hanya ada pada riwayal-riwayat dalam kitab-kitab Hadīì Sy’̀’ah. Lihat: Taimiyah, Minhäj Al-Sunnah Al-Nabawiyah vol. 7, p. 500.

53 Al-Ṭūsi dalam kitab tafsirnya mengatakan bahwa sesungguhnya telah banyak riwayat mutawatir yang membatasi ilmu al-Qur'ān hanya dimiliki oleh Rasūlullāh dan para imām. Lihat: Muhammad bin al-Hasan Al-Ṭūsī, Al-Tibyan Fì Tafsìr Al-Qur'ān (Beirut: Dār Ihyā̄ al-Turās al'Arabī, 1997) vol. 1, p. 4.

${ }^{54}$ Sayid al-Ṭabāțabā $\overline{1}$ (w. 1402H) mengatakan: "Terdapat banyak pertentangan dan ketidakmurnian dalam riwayal-riwayat yang bersumber dari mufassir sahabat dan tabi in." Lihat: Al-Ṭabațaba'̄i, Al-Mì̃ān Fì Tafsìr Al-Qur'ān vol. 1, p. 13; Senada dengannya adalah al-Faid alKashani (w. $1091 \mathrm{H}$ ), ia mengatakan bahwa para sahabat adalah orang-orang yang paling pandai menyembunyikan kemunafikan. Karenanya, tidak boleh meriwayatkan Ḥadīs atau mengambil tafsīir dari mereka. Lihat: Muhsin al-Faiḍ Al-Kashānī, Al-Tafsìr Al-Ṣafǐ (Qom, Iran: Mashnurāt Maktabah ash-Șadr, 1993) vol. 1, p. 43. 
Pertama, bagaimana mungkin al-Qur'ān dikatakan seperti itu agar dapat menjadi petunjuk bagi manusia? Padahal Allāh telah berfirman: "Sesungguhnya alQur'än ini memberikan petunjuk kepada (jalan) yang lebih lurus.,

Ibnu 'Abbās R.a. berkata: "Allāh menjamin orang yang membaca alQur'ān dan melaksanakan apa yang ada di dalamnya tidak akan tersesat di dunia dan tidak akan celaka di akhirat." ${ }^{56}$ Kemudia beliau membacakan ayat ini: "Turunlah kamu berdua dari surga bersama-sama, sebagian kamu menjadi musub bagi sebagian yang lain. Maka jika datang kepadamu petunjuk daripada-Ku, lalu barang siapa yang mengikut petunjuk-Ku, ia tidak akan sesat dan tidak akan celaka., ${ }^{, 57}$

Kedua, 'Alī bin Abī Țālib R.a. menandaskan, "Kitābullāh ini memuat berita sebelum kalian, berita setelah kalian, dan hukum diantara kalian; ia adalah Kitāb pemisah dan bukan permainan. Barangsiapa meinggalkannya, niscaya Allāh memurkainya. Ia adalah jalan yang lurus, yang dengannya nafsu tidak diperturutkan; perkataan (isinya) tidak samar; keajaibannya tidak pernah habis; dan para ulama tidak pernah merasa puas untuk mempelajarinya. Barangsiapa berkata berdasarkan al-Qur'ān, pastilah ia benar. Barangsiapa mengamalkannya pastilah ia mendapat pahala. Barangsiapa memutuskan hukum dengannya, pastilah ia berbuat adil. Dan, barangsiapa mengajak kepadanya, pastilah ia ditunjuki ke jalan yang benar." ${ }^{, 58}$

Ketiga, kitab Nahjul Balägah yang dialamatkan kepada 'Alī, yang oleh Syì'ah dijadikan salah satu referensi terpenting, memuat pernyataan: “Al-Qur'ān adalah sesuatu yang memerintahkan dengan tegas; sesuatu yang diam namun berbicara. Ia adalah huijah Allāh terhadap makhluk-Nya." ${ }^{, 59}$

Redaksi-redaksi seperti ini menunjukkan kepada kita bagaimana inkoherensi yang terjadi pada sumber-sumber referensi mereka. Antara yang satu dengan yang lainnya saling bertentangan. Namun, ketika terjadi kontradiksi, mereka menggunakan metode mengambil ajaran yang menyalahi pendapat umum (Sunnî). Orang yang memperhatikan perkataan yang tercantum luas dalam kitab-kitab Syìah, pasti menyadari itu merupakan karya musuh yang dengki dan sengaja menghalang-halangi manusia dari petunjuk Allāh.

${ }^{55}$ QS. Al-Isra': 9 (n.d.).

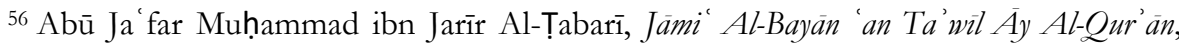
ed. Ahmad Muhammad Syakir (Beirut: Muassasah al-Risalah, 2000) vol. 16, p. 225.

${ }^{57}$ QS. Thaha: 123 (n.d.).

${ }^{58}$ Ibnu Kas̀īr, Faḍäil Al-Qur'ān (Beirut: Maktabah Ibnu Taimiyah, 1994) p. 15.

${ }^{59}$ Muhammad bin al-Husain bin Musā, Nabjul Balägah (Qom, Iran: Markaz al-Abhā̇ alI'tiqādiyah, 2002) p. 265. 
Keempat, berhubung ajaran tersebut menautkan kelayakan al-Qur'ān sebagai huijah dengan adanya qayyim (pengawas/supervisor) yang tidak lain adalah salah satu dari dua belas imām, maka al-Qur'ān hanya bisa ditafsirkan satu orang saja, yaitu 'Alī. Dan, ilmu al-Qur' ān tersebut telah berpindah dari 'Alī kepada dua belas imām. Kemudian masing-masing dari imām itu meneruskan ilmu tersebut kepada imām-imām setelahnya, sampai kepada imām kedua belas.

Imām yang kedua belas itu hilang, menurut Syī'ah Is̉na 'Ashariyah sejak dua belas abad lebih. ${ }^{60}$ Sedangkan menurut golongan Syìah yang lain, imām kedua belas itu tidak ada. ${ }^{61}$ Selagi kelayakan al-Qur'ān sebagai huijah digantungkan pada orang yang hilang atau tidak ada, itu berarti al-Qur'ān tidak bisa dijadikan hujjah. Dengan demikian, kenyataan ini semakin memperjelas bahwa doktrin dan keyakinan mereka adalah sesat.

Kelima, salah satu hal yang dipahami secara luas dalam Islām adalah ilmu al-Qur'ān bukanlah sesuatu rahasia yang hanya diwarisi keturunan tertentu. 'Alī R.a. tidak mendapatkan keistimewaan ini dengan meniadakan sahabat-sahabat yang lain. Selain itu, telah banyak naș yang menyatakan bahwa para sahabat adalah generasi pertama yang mendapatkan kemuliaan. Mereka mendengarkan langsung al-Qur'ān dari Rasūlullāh SAW., kemudian mendakwahkannya kepada manusia, hingga dilanjutkan oleh generasi berikutnya. ${ }^{62}$

Klaim bahwa ilmu al-Qur'ān hanya dimiliki oleh dua belas imām Syìah adalah sesuatu yang mengada-ada. Sebagian sumber Ahlussunnah menyebutkan bahwa ide ini muncul pertama kali dari Ibnu Saba'. Dialah yag mengatakan bahwa al-Qur'ān itu merupakan satu dari sembilan bagian ilmu yang ada pada 'Alī. ${ }^{63}$ Perkataan tersebut banyak tercantum dalam kitab-kitab Syì ah dengan berbagai berita dan riwayat. ${ }^{64}$

Perkataan-perkataan itu dapat ditolak dengan firman Allāh SWT. tentang orang yang mencari bukti kebenaran Rasūlullāh SAW: "Dan apakah tidak cukup 2009) p. 136

${ }^{60}$ Sayid 'Udnan Al-Bakā', Al-Imām Al-Mahdī Al-Muntą̧har (Qom, Iran: Dār Sulunī,

${ }^{61}$ Ibnu Șabbag Al-Malikī, Al-Fuṣūl Al-Mubimmah Fì Ma'rifati Ahwāli Al-Aimmah (Qom, Iran: Dār al-Aḍ̂wa' li al-Ṭibā'ah wa an-Nashr wa al-Tauzî̀, 1988) p. 288-289.

${ }^{62}$ Mengenai keutamaan para sahabat Nabī telah banyak Ḥadīs dan ayat yang menjelaskannya, seperti sabdanya: "Sebaik-baik generasi adalah generasiku (para sahabat), kemudian setelahnya, dan kemudian setelahnya." (HR. Al-Bukhārī dan Muslim). Adapun ayalayat al-Qur'ān, diantaranya adalah Āli 'Imrān: 110, an-Nisa': 115, al-Taubah: 100, dan lain-lain.

${ }^{63}$ Ibrāhīm bin Ya’qūb Al-Jurjānī, Aḥwāl Ar-Rijäl (Beirut: Muassasah al-Risalah, 1983) p. 38.

${ }^{64}$ Diantara riwayat palsu tersebut adalah: "Sesungguhnya Allāh telah menurunkan kepadaku al-Qur'ān. Barangsiapa menyimpang darinya maka akan tersesat. Dan barangsiapa mencari ilmunya pada selain "Alī maka akan binasa." 
bagi mereka bahwasanya Kami telah menurunkan kepadamu al-Kitāb (alQur'ān) sedang dia dibacakan kepada mereka?",65

Dan dalam ayat lainnya: "Dan Kami turunkan kepadamu al-Qur'ān, agar kamu menerangkan kepada umat manusia apa yang telah diturunkan kepada mereka dan supaya mereka memikirkan." 66

Ayat di atas menunjukkan bahwa keterangan-keterangan al-Qur'ān diperuntukkan kepada seluruh manusia, bukan satu orang atau satu golongan saja, sekalipun mereka adalah Ahlulbait. Bahkan, dalam riwayat Muslim, 'Alī bin Abī Țālib menafikan secara tegas persangkaan bahwa Rasūlullāh SAW. telah mengkhususkan ilmu kepadanya. Dari Abū Țufail berkata, bahwa kami berkata kepada 'Alī: "Kabarkanlah sesuatu yang Rasūlullāh rahasiakan kepadamu!" 'Alī menjawab: "Nabī tidak pernah merahasiakan sesuatu kepadaku, yang manusia tidak mengetahuinya." 67

\section{Pengaruh Makna Bāṭinī Terhadap Ẓāhir}

Keberadaan makna tersirat (bāṭinî) dalam al-Qur'ān memberikan pengaruh yang signifikan pada makna-makna tersuratnya (zāhir). Termasuk dalam kategori zāhir adalah ayat-ayat yang bersifat umum, mutlak, dan yang masih muhtamal (adanya kemungkinan dimaknai dengan makna lain). ${ }^{68}$ Secara

${ }^{65}$ QS. Al-Ankabut: 51 (n.d.).

${ }^{66}$ QS. Al-Nahl: 44 (n.d.).

${ }^{67}$ Musnad Ahmad (855) dan Shahih Muslim 1978; teks aslinya sebagai berikut:

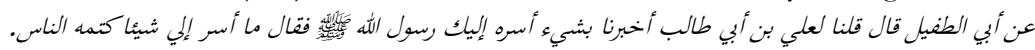

${ }^{68}$ Salah seorang ulama mereka (al-Muẓaffar) membicarakan tentang pokok-pokok lafal. Dan dia membatasinya pada lima bagian. Pertama, așalah al-haqiqah, yaitu pokok yang mengandung makna hakiki. Kedua, așalah al-umüm (pokok yang umum). Ketiga, așalah al-ițlāq (pokok yang mutlak). Keempat, așalah 'adam al-taqdir (pokok yang tidak ada ukurannya). Kelima, așalab zu ubūr (pokok yang zāhir). Saat membincang tentang așalab ini dia berkata: "Gambarannya adalah tatkala sebuah lafal secara zāaih memiliki makna khusus bukan dalam bentuk naș yang kemungkinan mengandung makna kbiläf, bahkan mungkin mengandung kemungkinan bersebrangan dengan yang zāhir. Maka pada saat demikian hendaknya sebuah perkataan diartikan dengan makna zahirnya saja." Sebenarnya semua Ușül yang disebutkan terdahulu itu kembali pada pokok ini. sebab lafal walaupun mengandung majaz (metafora) -misalnya- telah tampak hakikatnya, dan walaupun kemungkinan mengandung kekhususan maka dia akan tampak umum, dan meskipun dia mengandung makna mengikat maka akan tampak mutlak, dan walaupun tampak memiliki perkiraan -takdir- akan tampak tidak ada. Apa yang dilakukan oleh așalah al-haqiqah adalah sama dengan apa yang ada pada așalah zuhür dalam hal kemungkinan pengkhususan. Demikianlah pada ușül yang telah disebutkan sebelumnya. Andaikan semua itu kita ibaratkan dengan așalah zu üür maka itu sudah sangat mewakili dan akan mencapai apa yang dimaksud. Sebab semua kembali ke așalah zuubür. Maka sebenarnya dalam pandangan kami tidak 
otomatis, dengan adanya makna bāțini, maka ia akan mengkhususkan yang umum, membatasi yang mutlak, memperjelas yang muhtamal atau bahkan menasakh yang zāhir. Demikian ini karena pendapat para imām lebih kuat derajat ke-ḥujah-annya dari pada teks ẓāhir dalam al-Kitāb maupun Sunnah. ${ }^{69}$

Muhammad Riḍā al-Muẓaffar (w. 1388 H) ${ }^{70}$ dalam Ușūl al-Fiqh-nya mengatakan: "Tidak boleh mengamalkan yang zāhir sebelum dicari hal-hal yang mengkhususkannya."71 Pernyataan ini ia perjelas lagi dalam bukunya, bahwa dalam al-Qur'ān yang mulia dan di dalam Sunnah, ada yang umum dan khusus, ada yang mutlak dan terikat. Dan perkara-perkara ini tidak akan diketahui kecuali melalui jalur Ahlulbait. Sebab, 'penghuni rumah' (Sạhibul Bait) lebih tahu apa yang ada di dalamnya. ${ }^{72}$

Sebagian ulama Syī’ah, seperti Muhammad 'Alī al-Kāẓimī (w. 1333 H), ${ }^{73}$ al-Muẓaffar dan lain-lain, berpendapat bahwa kata-kata (Tafsīr Bāținī) yang mengkhususkan itu terkadang sekaligus menghapus hukum-hukum yang umum. Disebutkan dalam Ușūl al-Fiqh lil Muzaffar," "Apabila ada yang mengkhususkan, maka sudah pasti ia me-nasakh hukum yang umum." "75 Selain itu, telah banyak riwayat yang menjelaskan bahwa perkataan seorang imām apabila bertentangan dengan zāhir naș, maka ia berkedudukan sebagai pe-nasakh hukum sebelumnya. Hal ini dalam doktrin Syìah adalah sebagai upaya penyempurnaan sharîat

ada ușūl yang lain, yang ada hanya satu așl, yakni așalah zuubūr. Lihat: Muhammad Riḍā AlMuẓaffar, Ușūl Al-Fiqh Li Al-Muzaaffar (Beirut: Dār al-Ta'ārif al-Mațbu’āt, 1991) vol. 1, p. 31-32.

${ }^{69}$ Muhammad Taqī Al-Hakìm, Al-Ușūl Al-'Ammah Li Al-Fiqh Al-Muqāran (Qom, Iran: Mu`assasah Alilbait li al-Ṭiba’ah wa al-Nashr, 1979) p. 66.

${ }^{70}$ Ia adalah salah satu ulama besar Syỉah abad ke -14 yang banyak menulis buku-buku tentang 'Aqäid dan Ușūl al-Figh. Buku Ușül al-Fiqh yang ditulisnya dinilai sebagai karya fenomenal dan menjadi salah satu rujukan utama dalam sekte-sekte Syìah.

${ }^{71}$ Al-Muẓaffar, Ușūl Al-Fiqh Li Al-Muzaffar vol. 1, p. 136.

${ }^{72}$ Al-Muz̧affar vol. 1, p. 141-142.

${ }^{73}$ Ia adalah Abdul Asim Muhammad 'Alī bin Hasan al-Kāẓimī al-Khurasānī, salah satu ulama yang dijadikan marja’ Sy’’’ah di Qum pada tahun 1905-1911.

${ }^{74}$ Al-Muẓaffar, Ușūl Al-Fiqh Li Al-Muẓaffar vol. 1, p. 143-144.

${ }^{75}$ Dalam Fawäid al-Ușūl, al-Kāẓimìi juga menjelaskan bahwa terputusnya wahyu tidak menafikan adanya nasakh. Sebab ada kemungkinan Rasūlullāh telah menitipkan hukum yang menasakh itu pada orang yang mendapat wasiat ('Alī). Dan orang yang mendapat wasiat ini memberikan mandat pada orang yang dia wasiati selanjutnya, hingga sampai waktunya untuk ditampakkan dan disampaikan. Pada satu sisi juga telah banyak kabar-kabar yang menyatakan penyerahan agama Allāh kepada para imām. Dan setelah penjelasan ini maka tidak ada lagi shubhat dan keraguan tentang kemungkinan adanya nasakh setelah wafatnya Rasūlullāh SAW. Lihat: Muhammad 'Alī Al-Kāẓimī, Fawāid Al-Ușūl (Qom, Iran: Mu`assasah al-Nashr al-Islāmi alTabi`ah li Jama’ah al-Mudarrisīn, 1982) vol. 4, p. 274. 
(tadarruj) atau karena kondisi yang sebelumnya mengharuskan untuk bertaqiyah. $^{76}$

Terkait statemen Syìah di atas, para ulama telah membantah hal tersebut. Diantaranya adalah Tãjuddīn bin al-Subki (w. $771 \mathrm{H}$ ). Dalam bukunya, Jam'u al-Jawāmi', ia menjelaskan bahwa memaknai lafal yang zāhir dari naṣ-naș alQur'ān selama berlandaskan pada dalil, maka hal itu adalah bentuk pentakwilan yang dibenarkan. Apabila tanpa dalil, maka itu adalah pentakwilan yang batil. Dan apabila berdasarkan angan-angan, maka itu adalah main-main, bukan ta'mil. . $^{77}$

Para ulama sepakat bahwa memberlakukan makna zāhir dari setiap lafal adalah wajib, selama tidak ada dalil-dalil yang menjauhkan dari makna tersebut. Selain itu, tidak boleh pula ada pembuangan (baif) kalimat selama penyebutan masih mungkin. Sebab, ungkapan yang tidak membutuhkan kalimat yang dibuang adalah lebih utama, menurut logika orang-orang yang berakal, dibandingkan ungkapan yang masih membutuhkan sesuatu yang dibuang. Mereka menegaskan bahwa tidak ada ungkapan majaz (termasuk pula pemaknaan bāṭinî) selama hakikat masih mungkin, sebab tidak menggunakan makna zāhir yang masih mungkin adalah membuang dalil tanpa alasan. ${ }^{78}$ Dengan demikian, pemaknaan secara bāținī yang terdapat dalam tafsir-tafsir Sy'’ah adalah pemaknaan yang sesat. Sebab, hal itu hakikatnya adalah memalingkan makna yang sudah logis kepada makna yang tidak berdasarkan dalil dan jauh dari maksud al-Qāil (Allāh). ${ }^{79}$

${ }^{76}$ Sebagian Syìah ada yang mengatakan bahwa makna bāținī itu ketika datang maka menasakh hukum zāair. Dan adapula yang mengatakan bahwa itu adalah sebagai bentuk taqiyah dan tadaruj (tahapan). Muḥtamal mengatakan: "Sesuatu yang umum bisa menjadi alat penjelas bagi hukum yang żāhir gambarannya, karena adanya maslahat yang mengharuskan penyembunyian hukum yang waqi' (rill), meskipun untuk maslahat taqiyyab (penyembunyian hukum demi perlindungan pada keimanan), atau untuk kepentingan tadarrij (bertahap) sebagaimana sudah sama-sama diketahui dari cara Rasūlullāh dalam menjelaskan sebuah hukum shariat." Lihat: Al-Muẓaffar, Ușūl Al-Fiqgh Li Al-Mużaffar vol. 1, p. 144.

${ }_{77}$ Täjuddīn bin Al-Subkī, Jam'u Al-Jawāmi' (Beirut: Daar al-Kutub al-'Ilmiyyah (DKI) Publisher, 2001) p. 54.

78 'Abdul 'Azīz bin Ahmad Al-Bukhārī, Kashful Asrār 'an Ușūli Fakhrul Islām (Beirut: Daar al-Kutub al-'Ilmiyyah (DKI) Publisher, 1997) vol. 1, p. 69.

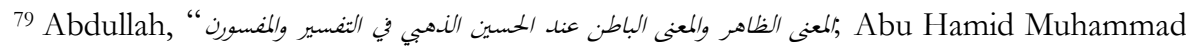

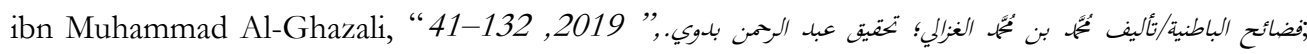
Farsat I Marie, “موقف علماء أهل السنة من التأويل الباطني عند الاسماعيلية," Humanities Journal of University of Zakho 6, no. 3 (2018): 820-36. 


\section{Contoh Penafsiran Bātịiñ}

Berikut beberpa contoh ayat yang ditasfirkan secara bātinī oleh para mufassir Syı̈’ah:

Pertama, "Janganlah kamu sembah di samping (menyembah) Allāh, tuhan apapun yang lain. Tidak ada Tuhan (yang berhak disembah) melainkan Dia. Tiap-tiap sesuatu pasti binasa, kecuali Allāh. Bagi-Nya lah segala penentuan, dan hanya kepada-Nya lah kamu dikembalikan." 80

Disebutkan dalam al-Burbān fì Tafsìr al-Qur'ān, bahwa Abū Ja'far pernah ditanya tentang ayat tersebut, maka ia berkata: "Segala sesuatu akan binasa dan yang tersisa hanya wajahnya. Dan Sesungguhnya Allāh Maha Agung dari pensifatan memiliki wajah. Maka maknanya adalah segala sesuatu akan binasa kecuali agama-Nya dan wajah yang datang dari-Nya (Alī bin Abī Ṭālib)." Dalam riwayat lain Abu Abdillāh menambahkan: "Dan kamilah (para imam) wajah Allāh itu.", 81

Para ulama telah membantah penafsirat tersebut. Diantaranya adalah Shaikh Muhammad al-Shinqiț̄i, ia mengatakan bahwa penafsiran Syī'ah tersebut sangatlah sesat. Selain telah menafikan Sifat, mereka juga memalingkan makna wajhah kepada makna yang batil. Apabila lafal tersebut ditafsirkan dengan makna imām, maka artinya ada dzat lain yang abadi selain Allah, dan Ia memiliki tandingan di dunia ini. Maha Suci Allāh atas tuduhan tersebut. ${ }^{82}$

Kedua, "Allāh menghapuskan apa yang Dia kehendaki dan menetapkan (apa yang Dia kehendaki), dan di sisi-Nya-lah terdapat Ummul Kitāb.",83

Menurut Syī'ah, ayat di atas merupakan dalil yang menerangkan tentang salah satu Sifat Allāh, yaitu $b a d \vec{a}{ }^{84}$ Artinya, tidaklah mustahil bagi Dia untuk membatalkan takdir yang telah diputuskan sebelumnya karena muncul pendapat atau hal-hal baru, yang sebelumnya masih samar-samar. ${ }^{85}$ Zurārah meriwayatkan dari Ja'far al-Ṣādiq, bahwa 'Alī bin Husain pernah berkata: “Demi Allāh, jika bukan karena sebuah ayat (tentang sifat badā), niscaya akan aku ceritakan kepada kalian apa saja yang akan terjadi hingga hari kiamat, (firmal-Nya) "Alläh

${ }^{80}$ QS. Al-Qashash: 88 (n.d.).

${ }^{81}$ Al-Baḥrānī, Al-Burbān Fì Tafsìr Al-Qứän vol. 1, p. 409.

${ }^{82}$ Muhammad Al-Shinqithī, Aḍwa' Al-Bayān F̌̄ Tafsìr Al-Qur'ān (Beirut: Dār Ihyā̄ alTurās̀ al-'Arabī, 1998) vol. 6, p. 233.

${ }^{83}$ QS. Al-Ra`d : 39 (n.d.).

${ }^{84}$ Muhammad bin al-Hasan Al-Ṭūsī, Al-Gaibah Li Al-Tūsì (Beirut: Muassasah al-Ma’ārif al-Islāmiyah, 1989) p. 263.

${ }^{85}$ Al-Majlisī, Bị̣ārul Anwār vol. 4, p. 108. 
menghapuskan apa yang Dia kehendaki dan menetapkan (apa yang Dia kehendaki), dan di sisi-Nya-lah terdapat Umul Kitab (Lauhul mahfüz).",86

Badā' merupakan sifat yang mustahil bagi Allāh dan bertentangan dengan Sifat-Sifat Mulia lainnya. Ayat tersebut menurut sebagian mufassir adalah membahas tentang hukum yang dihapus dan hukum yang menggantikan, atau dalam istilah ilmu al-Qur'ān disebut nasakh mansükeh. ${ }^{87}$ Dan menurut sebagian mufassir lainnya, ia menjelaskan tentang takdir. Maksudnya, ada takdir hamba yang Allāh hilangkan kemudian diganti dengan yang lain, dan semua itu sudah Allāh tuliskan sejak zaman 'azaliz. ${ }^{88}$ Dengan demikian, sangatlah tidak tepat apabila ayat tersebut ditafsirkan sebagai justifikasi Allāh memiliki sifat badä'.

Ketiga, "Dia membiarkan dua lautan mengalir yang keduanya kemudian bertemu, antara keduanya ada batas yang tidak dilampaui oleh masing-masing... Dari keduanya keluar mutiara dan marjan." 89

Seorang pemuka Syī'ah, Ibnu al-Muțahhār al-Hillī (w. $747 \mathrm{H}$ ) ${ }^{90}$ telah menafsirkan ayat di atas, bahwa yang dimaksud dengan pertemuan dua lautan adalah pertemuan 'Alī bin Abī Țālib dan Fațimah al-Zahra'. Sedangkan "Antara keduanya ada batas yang tidak dilampani oleh masing-masing", maksudnya adalah Nabī SAW. Dan: "Dari keduanya keluar mutiara dan marjan", maksudnya adalah alHasan dan al-Husain. ${ }^{91}$ Ketika Ibnu al-Muțahhār mengemukakan ini, Shaikhul Islām Ibnu Taimiyah berkomentar: "Perkataan ini dan yang semisalnya hanya dilontarkan orang yang tidak memahami apa yang dikatakannya. Sepintas ia seperti penafsiran al-Qur'ān, padahal ini sejenis dengan Tafsīr al-Mulāhidah, alQāramițah dan al-Bāṭiniyah terhadap al-Qur'ān. Bahkan, lebih buruk lagi, tafsir

${ }^{86}$ Al-Majlisī vol. 4, p. 118.

${ }^{87}$ Mokhtar Mohd Fuad, "Ihsan Ilahi Zahir (1945-1987) Dan Kritikannya Terhadap Pemikiran Akidah Syiah/Mohd Fuad Mokhtar" (University of Malaya, 2016) p. 69-71; Mohd Hamidi Ismail and Mohd Fauzi Hamat, "Pengisbatan Al-Imamah Melalui Al-Bada' Menurut Syiah Al-Ithna Ashariyyah,” Jurnal Akidah \& Pemikiran Islam 18, no. 1 (2016): 1-42.

88 'azali adalah masa dimana Allāh SWT. menuliskan takdir untuk seluruh makhluknya, yaitu sebelum Ia menciptakan langit dan bumi (setelah diciptakannya al-qalam). Lihat: 'Alī Muhammad Ash-Șalabī, Iman Kepada Qadar, Diterjemabkan Oleh Darwo Mariyono (Solo: UmmulQura, 2014) vol. 6, p. 101.

${ }^{89}$ QS. Al-Rahmān: 19-22 (n.d.).

${ }^{90}$ Ia adalah Jamāluddin al-Hasan bin Yusuf bin 'Alī bin al-Muțahhār al-Hillī, seorang mufassir ternama di kalangan Syì ah yang hidup pada abad ke-8 H. Karena pengaruhnya yang cukup besar dalam mendakwah ajaran Syì ah, maka ia digelari al-'Alamah.

${ }^{91}$ Al-Qummī, Tafsì Al-Qummi vol. 2, p. 65. 
seperti ini merupakan salah satu macam penjelek-jelekan terbesar terhadap alQư'ān.",92

Keempat, "(Bujukan orang-orang munafik itu adalah) seperti (bujukan) setan ketika dia berkata kepada manusia: "Kafirlah kamu", maka tatkala manusia itu telah kafir ia berkata: "Sesungguhnya aku berlepas diri dari kamu karena sesungguhnya aku takut kepada Allāh Tuhan semesta alam."93

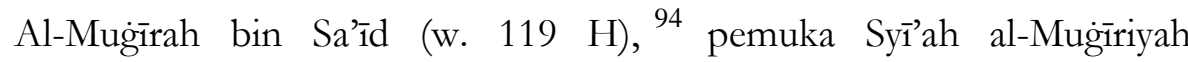
menafsirkan ayat di atas, bahwa yang dimaksud 'setan yang mengajak kepada kekufuran' adalah 'Umar bin al-Khațab. Penafsiran tersebut diadopsi oleh sekte Syi'ah Is̉na 'Ashariyah dan dicantumkan dalam kitab-kitab tafsir mereka, seperti: al-Tyāshì, ${ }^{95}$ al-Safì, ${ }^{96}$ al-Qummì, ${ }^{97}$ al-Burbān, ${ }^{98}$ Bihärul Anwār dan lain-lain. ${ }^{99}$

Penafsiran al-Mugīirah ini sangatlah kontroversi. Telah banyak ulama yang men-tahìir dirinya melakukan berbagai distorsi. Bahkan, tidak hanya ulama Sunnī saja, imām al-Dhahabī meriwayatkan dari Kasīìr al-Nuwa ${ }^{100}$ bahwa Abū Ja'far mengatakan: "Allāh dan Rasul-Nya berlepas diri dari al-Mugīirah bin Sa'̄̄d dan Bayān bin Sam'an, karena keduanya telah berbohong atas nama kami, Ahlulbait." ${ }^{101}$ Al-Kishī juga meriwayatkan yang serupa dari Abū Abdillāh Ja'far al-Șādiq, bahwa orang yang dianggap imām keenam ini pun mengingkari apa yang telah ditafsirkan oleh al-Mugīirah dari ayat-ayat al-Qur'ān. ${ }^{102}$

Kelima, "Dan di antara kaum Musā itu terdapat suatu umat yang memberi petunjuk (kepada manusia) dengan hak dan dengan yang hak itulah mereka menjalankan keadilan." 103

Ayat ini ditafsirkan secara bāṭinī oleh mufassir Syīah, bahwa umat Islām yang setia kepada Ahlulbait adalah yang mendapatkan petunjuk. ${ }^{104}$ Padahal,

92 Taimiyah, Minhäaj Al-Sunnah Al-Nabawiyah vol. 4, p. 66.

${ }^{93}$ QS. Al-Hasyr: 16 (n.d.).

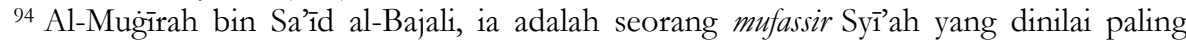
ekstrimis dalam menafsirkan ayal-ayat al-Qur'ān.

${ }^{95}$ Al-Samarqandī, Tafsìr Al-'Iyāshì vol. 2, p. 223.

${ }^{96}$ Al-Kashānī, Al-Tafsìr Al-Safì vol. 3, p. 223.

${ }^{97}$ Al-Qummī, Tafsì Al-Qummì vol. 3, p. 84.

${ }^{98}$ Al-Baḥrānī, Al-Burbān Fì Tafsìr Al-Qur'än vol. 2, p. 309.

${ }^{99}$ Al-Majlisī, Biḥārul Anwār vol. 3, p. 378.

${ }^{100}$ Kasīir an-Nuwa' adalah seorang Syìah; salah satu riwayat menyebutkan bahwa ia keluar dari Syı̀’ah.

${ }_{101}$ Muhammad bin Ahmad al-Żahabī, Mǐzan Al-I’tidal (Riyāọ: Shabkah Mishkāt alIslāmiyah, 1998) vol. 4, p. 161.

${ }^{102}$ Muhammad bin 'Umar Al-Kishī, Rijäl Al-Kishì (Qom, Iran: Mu`assasah an-Nashr alIslāmi al-Tabi ah li Jama’ah al-Mudarrisīn, 2005) p. 195.

103 QS. Al-A raf: 159 (n.d.). 
zāhir ayat ini adalah pelajaran dari kaum Nabī Musā A.S. bahwa diantara Banī Isrāīl ada yang mendapatkan petunjuk dari Allāh SWT. ${ }^{105}$

Keenam, "Sesungguhnya kamu melalui tingkat demi tingkat (dalam kehidupan)."

Menurut sebagian mufassir mereka, ayat ini mengisyaratkan bahwa umat Islām akan menempuh jalannya umat-umat terdahulu yang telah menghianati para penerima wasiat dari Nabī mereka. ${ }^{107}$ Padahal, ayat ini berbicara tentang tahap demi tahap penciptaan manusia, mulai dari nutfah, 'alaqah, mudgiah, rüh, hidup dan mati, lalu kebangkitan dari alam kubur menuju akhirat. ${ }^{108}$

\section{Identifikasi Imāmah-sentris pada Tafsīr Bāținī Syī’ah}

Berdasarkan data-data yang penulis paparkan sebelumnya, Tafsīr Bāținī telah menimbulkan kontroversi yang cukup besar dalam pentakwilan naș. Dengan penafsiran seperti itu, kredibilitas Tafsīr Batinī menjadi layak untuk dikaji lebih lanjut. Sarjana seperti 'Alī Muhammad al-Ṣalabī dan Etan Kohlberg menyebutkan bahwa penafsiran secara bāținī justru lebih merupakan upaya orientatif menuju imämah-sentris. ${ }^{109}$ Bahkan, Imam Ghazālī dalam bukunya Fadhäih al-Bätiniyyah telah lebih dahulu menguraikan secara kritis perbedaan imämah perspektif Sunni dan Syı̈ah. ${ }^{110} \mathrm{Hal}$ ini akan relevan dengan contoh berikut:

\section{Makna Tauhīd Menjadi Kewalian Imāmah}

Distorsi penafsiran atau tahrif ayat-ayat al-Qur'ān diarahkan untuk menegaskan kedudukan imām dalam tauhīd. Abū Ja'far mengatakan: "Setiap kali

${ }^{104}$ Al-Baḥrānī, Al-Burbān Fì Tafsìr Al-Qur'ān vol. 5, p. 413-416.

105 Al-Husain bin Mas'ūd Al-Bagawī, Ma'älim Al-Tanzìl Fì Tafsìr Al-Qur'ān (Beirut: Dar 'Thya' al-Turats al-A'rabi, 1998) vol. 2, p. 240.

106 QS. Al-Insyiqāq: 19 (n.d.).

107 Al-Qummī, Tafsì Al-Qummi vol. 2, p. 412.

108 Al-Shinqithī, Adwa' Al-Bayān Fì Tafsìr Al-Qur'än vol. 9, p. 120.

109 'Alī M. Al-Șalabī, Fiker Al-Khawärij Wa Al-Shi ab Fì Mǐran Ablussunnah Wal Jama'ah (Cairo: Dār Ibnu Hazm, 2007) p. 266-268; Etan Kohlberg, "Imam and Community in the PreGhayba Period," in In Praise of the Few. Studies in Shi?I Thought and History (Brill, 2020), 187-212; Syamsuddin Arif, Bukan Sekedar Madžhab: Oposisi Dan Heterodoksi Syiah (Jakarta: INSISTS Jakarta, 2018).

110 Syamsul Yakin, "Kritik Al-Ghazali Terhadap Aliran Bathiniyah Terkait Konflik Politik Sunni Dan Syiah Di Panggung Sejarah," Refleksi 16, no. 1 (2017): 105-30; Al-Ghazali,

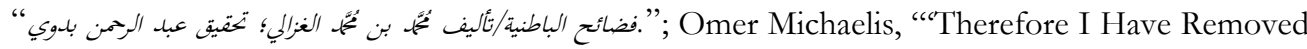
the Veil': Disclosure of Secrets in Eleventh-Century Islam and the Literary Character of Maimonides's Guide," Harvard Theological Review 113, no. 3 (2020): 378-404. 
Allāh mengutus seorang Nabī, pastilah dengan membawa kewalian kami dan berlepas diri dari musuh kami, ${ }^{111}$ sebagaimana tersebut dalam firman-Nya: "Dan sesungguhnya Kami telah mengutus rasul pada tiap-tiap umat (untuk menyerukan): "Sembahlah Alläh (saja), dan jaubilah Tạagùt itu", maka di antara umat itu ada orangorang yang diberi petunjuk. oleh Alläh dan ada pula di antaranya orang-orang yang telah pasti kesesatan baginya. Maka berjalanlah kamu di muka bumi dan perhatikanlah bagaimana kesudahan orang-orang yang mendustakan (rasul-rasul)." 112 Artinya, riwayat ini ingin menyatakan bahwa kedudukan wilāyah/imāmah para imām Syìah adalah sepadan dengan tauhīd dan menyembah Allāh, sedangkan para penentang iman adalah țägüt yang wajib dijauhi. ${ }^{113}$ Sebenarnya, tidak ada kalimat atau kata yang mengarah pada pengertian iman, tapi inilah tafsīr Syì’ah.

\section{Makna Allāh Menjadi Makna Imām}

Penyimpangan kedua adalah menafsirkan keesaan Tuhan dengan keesaan dalam mengangkat imām. Maka firman Allāh: "Janganlah kamu menyembah dua Tuban; sesunggubnya Dia-lab Tuban Yang Maha Esa, maka bendaklah kepada-Ku saja kamu takut", ${ }^{114}$ ditafsirkan oleh Abū Abdillāh dengan jangan engkau mengangkat dua imām karena imām itu hanya satu seorang. ${ }^{11}$

\section{Makna al-Fạ̣l Menjadi Para Imām}

Ihwal firman Allāh: "Apakah mereka mempunyai sembahan-sembahan selain Allāh yang mensyariatkan untuk mereka agama yang tidak diizinkan Allāh? Sekiranya tak ada ketetapan yang menentukan (dari Allāh) tentulah mereka telah dibinasakan. Dan sesungguhnya orang-orang yang zalim itu akan memperoleh azab yang amat pedih." ${ }^{116}$ Lafal al-Fașl pada ayat ini ditafsirkan oleh ulama Syı̀’ah sebagai imām-imām Syì’ah. ${ }^{117}$

\section{Makna Masjid menjadi Para Imām} imām, ${ }^{118}$ seperti yang terdapat pada ayat berikut: "Dan sesungguhnya masjidmasjid itu adalah kepunyaan Allāh. Maka janganlah kamu menyembah seseorang pun di dalamnya di samping (menyembah) Allāh." ${ }^{119}$ Ayat ini ditafsirkan oleh

\footnotetext{
111 Al-Baḥrānī, Al-Burbān F̌̀ Tafsìr Al-Qưr'än vol. 8, p. 104.

112 QS. Al-Naḥl: 36 (n.d.).

113 Al-Samarqandī, Tafsìr Al-'Tyāshì vol. 2, p. 261.

${ }^{114}$ QS. Al-Naḥl: 51 (n.d.).

115 Al-Baḥrānī, Al-Burbān F̌̀ Tafsìr Al-Qứ'ān vol. 2, p. 373.

${ }_{116}$ QS. Al-Syūrā: 21 (n.d.).

117 Al-Majlisī, Biḥārul Anwàr vol. 24, p. 174.

118 Al-Samarqandī, Tafsìr Al-'Iyāshì vol. 2, p. 13.

${ }^{119}$ QS. Al-Jinn: 18 (n.d.).
} 
mereka bahwa imām adalah dari keluarga Muhammad, maka jangan angkat seseorang selain mereka sebagai imām. ${ }^{120}$

\section{Makna Taubat}

Jika sebelumnya kata-kata tertentu dalam al-Qur'ān diartikan sebagai imām, kini mereka menafsirkan makna taubat menjadi keluar dari kewalian Abū Bakar, 'Umar dan 'Ujsmān. Firman Allāh: "(Malaikat-malaikat) yang memikul 'Arash dan malaikat yang berada di sekelilingnya bertasbih memuji Tubannya dan mereka beriman kepada-Nya serta memintakan ampun bagi orang-orang yang beriman (seraya mengucapkan): "Ya Tuhan kami, rahmat dan ilmu Engkau meliputi segala sesuatu, maka berilah ampunan kepada orang-orang yang bertaubat dan mengikuti jalan Engkau dan peliharalab mereka dari siksaan neraka yang menyala-nyala. "121 Kata taubat pada ayat tersebut ditafsirkan bahwa maksudnya adalah bertaubat dari kewalian tiga täğ (Abu Bakar, 'Umar dan 'Uśmān) dan Bani Umayyah. Sedangkan makna: "dan mengikuti jalan Engkau" maksudnya adalah kewalian 'Alī. 122

Riwayat di atas dinisbatkan kepada Abū Ja'far Muhammad al-Bāqir. Padahal, al-Bāqir sendiri menafikan penisbatan tafsir semacam itu. Contohcontoh di atas hanya sedikit dari sekian banyak penafsiran mereka yang mengikuti corak bātịn̄̄ (makna tersirat) yang diadopsi dari Abul Khațāb, Jābir alJu'fī, al-Mug̈īrah bin Sa’̄id dan lainnya.

\section{Telaah Kritis}

Jika kita telaah secara detail, bahwa relasi ideologi imāmah dengan Tafsīr Bāṭin̄̄ sangatlah jelas. Hal ini membedakan antara Tafsīr Bāțin̄̄ Syīah yang sering diafiliasikan dengan Tafsīr Sufistik atau Isyārī, dengan Tafsir Sufistik atau Isyārī yang disebut terpuji (mahmūd) oleh beberapa ulama seperti Imām Ghazali sebagai representasi Asy’āriyah berikut pula ulama Kalām lainnya; hingga para sufi seperti Ibn Arabi, Qusyaeri, dan lainnya. Pada posisi inilah, uraian ini menegaskan demarkasi antara tafsīr Isyārī Sunn̄̄ yang meski menggunakan makna Bāṭin sebagaimana Tafsir Sufistik; namun tetap mengafirmasi bahwa syariah dan aqidah Islam tidak diderivasi dari para Imām Ma'sūm sebagaimana pada Tafsir (Isyārī) Bāttin̄̄ model Sȳ̄ah.

120 Al-Baḥrānī, Al-Burbān F̌̀ Tafsìr Al-Qứ'ān vol. 4, p. 393.

${ }^{121}$ QS. Ġāfir: 7 (n.d.).

122 Al-Kashānī, Al-Tafsìr Al-Ṣafì vol. 4, p. 335; Al-Qummī, Tafsìr Al-Qummì vol. 2, p. 255. 


\section{Kesimpulan}

Dari pembahasan di atas dapat disimpulkan bahwa metode Tafsīr Bāținī Syīah memiliki corak yang berbeda dengan Tafsīr Sunni. Karena, bagi Syīah, metode tersebut adalah satu-satunya metode penafsiran yang paling valid. Sehingga, Syı̀’ah membatasi bahwa ilmu al-Qur'ān, termasuk di dalamnya makna bāținī, hanya dimiliki oleh para imām yang ma'ṣum. Hal ini ditandai dengan penegasan mereka bahwa makna bāțin̄̄ lebih utama dari makna zāhir. Apabila terjadi kontradiksi, maka zāhir naṣ ter-mansükh oleh makna bātini-nya. Berbeda dengan Ahlussunnah yang mengakui adanya makna tersurat (zähir) dan tersirat (ishāri) dalam al-Qur'ān, Metode Tafsīr Bāțin̄̄ cenderung digunakan Syì’ah untuk meneguhkan ideologi imāmah; sebagaimana telah diketahui oleh para ulama Sunni sejak lama.

\section{Bibliografi}

Abdullah, Muhammad Farid. "المعنى الظاهر والمعنى الباطن عند الحسين الذهبي في التفسير والمفسورن." LIS ANLA: Journal of Arabic Education and Literature 1, no. 1 (2017): 74-90. Abidin, Ahmad Zainal. "Shi'ite Ideology Bias in Al-Qummi Tafsir: Study of Ali Imran and Al-Nisa' Chapters." ESENSLA: Jurnal Ilmu-Ilmu Ushuluddin 19, no. 2 (2018): 185-97.

Ahmad Mukhtar Abdul Hamid, Umar. Mu'jam Al-Lughah Al-Arabiyah AlMu'ashirah (Lexicon of the Modern Arabic Language). Vol. 2 p. Cairo: Alam Al-Kutub, 2008.

Al-'Arabī, Abū Bakar bin. Al-'Awāṣim Min Al-Qawāṣim. Cairo: Maktabah Dār alTurās, 1999.

Al-'Āmilī, Muhammad bin al-Hasan. Al-Fașl Al-Muhimmah Fì Ușūl Al-Aimmah. Qom, Iran: Mu'assasah Ma'ārif Islāmī, 1998.

. Wasā'il Al-Syìah. Qom, Iran: Mu'assasah Alilbait lil Ihyā’ al-Turāì, 1992.

Al-Bağawī, Al-Husain bin Mas'ūd. Ma'ālim Al-Tanz̄ll F̌̀ Tafsìr Al-Qur'ān. Beirut: Dar 'Ihya' al-Turats al-A'rabi, 1998.

Al-Baḥrānī, Sayid Hāshim. Al-Burhān Fē Tafsìr Al-Qur'ān. Qom, Iran: Manshurat Mu `assasah al-A 'lami li al-Mathbu’at, 2006.

Al-Bakā', Sayid 'Udnan. Al-Imām Al-Mahdì Al-Muntą̧har. Qom, Iran: Dār Sulunī, 2009.

Al-Barq̄̄i, Ahmad bin Muhammad. Al-Mahāsin. Qom, Iran: al-Majma' al-'Alāmī lì Ahlilbait, 2014.

Al-Bukhārī, 'Abdul 'Az̄̄z bin Ahmad. Kashful Asrār 'an Ușūli Fakhrul Islàm. Beirut: Daar al-Kutub al-'Ilmiyyah (DKI) Publisher, 1997.

Al-Faqihī, 'Al̄̄ bin Muhammad. Dirāsah 'an Al-Firāq Fì Tärìkh Al-Muslimin. Madīnah: al-Jami`ah al-Islāmiyah, 1995. 
Al-Ghazali, Abu Hamid Muhammad ibn Muhammad. " فضائح الباطنية/تأليف محمد بن الرجئ

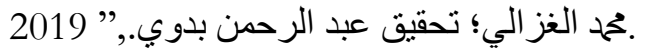

Al-Hakīm, Muhammad Taqī. Al-Ușül Al-'Ammah Li Al-Fiqh Al-Muqäran. Qom, Iran: Mu`assasah Alilbait li al-Tiiba’ah wa al-Nashr, 1979.

Al-Jurjān̄̄, Ibrāhīm bin Ya'qūb. Ahwwāl Ar-Rijäl. Beirut: Muassasah al-Risalah, 1983.

Al-Kashānī, Muhsin al-Faiḍ. Al-Tafsìr Al-Ṣafì. Qom, Iran: Mashnurāt Maktabah ash-Șadr, 1993.

Al-Kāẓimī, Muhammad 'Alī. Fawäì Al-Ușūl. Qom, Iran: Mu’assasah al-Nashr al-Islāmi al-Tabi ah li Jama’ah al-Mudarrisīn, 1982.

Al-Kishī, Muhammad bin 'Umar. Rijäl Al-Kishì. Qom, Iran: Mu'assasah anNashr al-Islāmi al-Tabi ah li Jama'ah al-Mudarrisīn, 2005.

Al-Kulainī, Muhammad Ya'qūb. Ușūl Al-Käfì. Beirut: Dār al-Ta'ārif al-Maṭbu’āt, 1990.

Al-Majlisīi, Muhammad Bāqir. Bihhārul Anwār. Beirut: Daar al-Kutub al-'Ilmiyyah (DKI) Publisher, 2000.

Al-Malikī, Ibnu Șabbag̀. Al-Fușül Al-Mubimmah Fì Ma'rifati Aḥwāil Al-Aimmah. Qom, Iran: Dār al-Aḍwa' li al-Ṭibā’ah wa an-Nashr wa al-Tauzì̄, 1988.

Al-Mashkinī, Alī. Isthilahāt Al-Ușl Wa Mu’zam Abhasỉha. Qom, Iran: Duftur Nashr al-Hādī, 1951.

Al-Muqrī, Ahmad bin Muhammad. Al-Mișbāh Al-Munìr. Madīnah: al-Maktabah al-'Ashriyah, 2008.

Al-Muẓaffar, Muhammad Rị̣ā. 'Aqāid Al-Imāmiyah. Beirut: Dār al-Ta'ārif alMaṭbu'āt, 1991.

—. Ușūl Al-Fiqh Li Al-Muzaffar. Beirut: Dār al-Ta'ārif al-Maṭbu'āt, 1991.

Al-Qațān, Mannā’ Khalīl. Mabāhisis Fì 'Ulüm Al-Qưr'ān. Madīnah: Dār al-Ma'ārif li an-Nashr wa al-Tauzì', 2000.

Al-Qifārī, Nașir. Ușūl Madz̧hab Al-Shì'ah Al Imāmiyah Al-Is̉nā 'Ashariyah. Riyāḍ: Mamlakah al-'Arabiyah al-Su'ūdiyah, 2007.

Al-Qummī, 'Alī bin Ibrāhīm. Tafsìr Al-Qummì. Beirut: Mu’assasah al-A'lā lil Mațbu'at, 1973.

Al-Qummī, Ibnu Babāwaih. Tlal Al-Shara'T̄. Najef: Manshurāt al-Maktabah alHaidāriyah wa Maṭba'uha, 1966.

- Amalì Al-Sadūq. Qom, Iran: Manshurat Mu`assasah al-A`lami li alMathbu'at, 2009.

Al-Sajistānī, Abdullāh bin Sulaimān. Al-Mașabif. Makkah: Dār al-Bashāir alIslāmiyah, 2002.

Al-Șalabī, 'Alī M. Fiker Al-Khawärij Wa Al-Sbi ah Fì Mižan Ablussunnah Wal Jama’ah. Cairo: Dār Ibnu Hazm, 2007. 
Al-Șalabī, 'Alī Muhammad. Sìrah Amìrul Mukminin 'Alì Bin Abì Tạalib. Beirut: Daar al-Fikr, 2005.

Al-Sālūs, 'Alī Ahmad. Ma'a Al-Shìah Al-Iśnā 'Ashariyah Fì Al-'Ușül Wa Al-Furū.' Cairo: Maktabah Dār al-Qur'ān, 2003.

Al-Samarqandī, Muhammad bin Mas'ūd bin 'Iyāshī. Tafsìr Al-'Iyāshì. Bag̀dād: alMaktabah al-'Ilmiyah al-Islāmiyah, 1994.

Al-Shinqithī, Muhammad. Aḍwa' Al-Bayān F̄̄Tafsìr Al-Qur'ān. Beirut: Dār Ihyā' al-Turāì al-'Arabī, 1998.

Al-Subkī, Tājuddīn bin. Jam'u Al-Jawàmi'. Beirut: Daar al-Kutub al-'Ilmiyyah (DKI) Publisher, 2001.

Al-Suyūṭị, Jalāluddin. Al-Dur Al-Mansìurr. Beirut: Daar al-Fikr, 1993.

- Al-Itqān Fì 'Ulūm Al-Qur'ān. Riyāḍ: Dār al-Hijrah li al-Nashr wa alTauzì', 1996.

Al-Ṭabarī, Abū Ja far Muḥammad ibn Jarīr. Jämi' Al-Bayān 'an Ta'wñl Āy AlQur'ann. Edited by Ahmad Muhammad Syakir. Beirut: Muassasah alRisalah, 2000.

Al-Ṭabațaba'ī, Sayid. Al-Mĩ̄àn Fì Tafsìr Al-Qur'än. Qom, Iran: Manshurat Mu`assasah al-A `lami li al-Mathbu'at, 1997.

Al-Ṭusīi, Muhammad bin al-Hasan. Al-Gaibah Li Al-Ṭusì. Beirut: Muassasah alMa’āirif al-Islāmiyah, 1989.

—. Al-Tibyan F̌̀ Tafsìr Al-Qur'ān. Beirut: Dār Ihyā’ al-Turās̀ al-'Arabī, 1997.

—. Rijäl Al-Käshì. Qom, Iran: Mu assasah an-Nashr al-Islāmi al-Tabi ah li Jama'ah al-Mudarrisīn, 2007.

Al-Żahabī, Muhammad Husain. Al-Tafsì Wa Al-Mufassirūn. Cairo: Maktabah Wahbah, 2003.

Ali, Ali Suleiman. Books-in-Brief: A Brief Introduction to Qur'anic Exegesis. International Institute of Islamic Thought (IIIT), 2018.

Amaliya, Niila Khoiru. "Arah Metodologi Tafsir Kontemporer." QALAMUNA: Jumal Pendidikan, Sosial, Dan Agama 10, no. 01 (2018).

An-Najafì, Muhammad Rị̣ā. Al-Syżah Wa Ar-Raj'ah. Bag̀dād: Maṭba'ah al-Adāb al-Ashrāf, 1990.

Aram, Mohammad Reza. "The Classical Tafsir Works Of Both Shias And Sunnis On The Interpretation of The Mustaqarr And Mustawda." European Journal of Science and Theology 11, no. 4 (2015): 13-22.

Arif, Syamsuddin. Bukan Sekedar Madz̧hab: Oposisi Dan Heterodoksi Syiah. Jakarta: INSISTS Jakarta, 2018.

Arsad, Muhammad. "Pendekatan dalam Tafsir (Tafsir bi Al Matsur, Tafsir bi Al Rayi, Tafsir bi Al Isyari)." Yurisprudentia: Jurnal Hukum Ekonomi 4, no. 2 (2018): 147-65.

Ash-Șalabī, 'Alī Muhammad. Iman Kepada Qadar, Diterjemabkan Oleh Darwo Mariyono. Solo: Ummul-Qura, 2014. 
Asy'ari, Muhammad Hasanil. "Menyingkap Tabir Dibalik Efistemologi Irfani. Doc." Jurnal Penelitian Tarbawi: Pendidikan Islam Dan Isu-Isu Sosial 3, no. 1 (2018): 9-20.

Esfahani, Seyyed Abdullah, and Seyyede Masoome Hosseini. "Comparative Analysis of 'Nature of Interpretation by Qur'an Judgment' from Shia and Sunni Commentators' Perspective." Journal of History Culture and Art Research 6, no. 3 (2017): 1199-1207.

Fauzan, Ahmad. "Manhaj Tafsir Al-Mizan Fi Tafsir Al-Qur'an Karya Muhammad Husain Tabataba'i." Al-Tadabbur: Jurnal Ilmu Al-Qur'an Dan Tafsir 3, no. 02 (2018): 117-36.

Haq, Sansan Ziaul. "Hermeneutika Sufistik: Telaah Epistemologi Takwil Ibn 'Arabi." At-Tibyan: Jurnal Ilmu Alqur'an Dan Tafsir 4, no. 1 (2019): 1-25.

Iqbal, Muhammad, and Ja'far Ja'far. "Contemporary Development of Qur'anic Exegesis In Indonesia And Iran." Journal of Contemporary Islam and Muslim Societies, 2019. https://doi.org/10.30821/jcims.v3i1.4144.

Ismail, Mohd Hamidi, and Mohd Fauzi Hamat. "Pengisbatan Al-Imamah Melalui Al-Bada' Menurut Syiah Al-Ithna Ashariyyah.” Jurnal Akidah \& Pemikiran Islam 18, no. 1 (2016): 1-42.

Jarullāh, Musā. Al-Wasyì'ah Fì Naqdi 'Aqäid Al-Syì'Ab. Pakistan: Sahīl Akadimī Lahūr, 1983.

Kas̀īr, Ibnu. Fadäül Al-Qur'än. Beirut: Maktabah Ibnu Taimiyah, 1994.

Khairuddin, Fiddian, and Amaruddin. "Mengungkap Penafsiran Al-Qur'an Versi Syiah Kajian Tafsir Al-Mizan Fi Tafsir Al-Qur'an Karya at-Tabataba'i." SYAHADAH 6, no. 2 (2018): 92-114.

Kohlberg, Etan. "Imam and Community in the Pre-Ghayba Period." In In Praise of the Few. Studies in Shi?I Thought and History, 187-212. Brill, 2020.

Madid, Izzul. "Tafsir Sufi: Kajian Atas Konsep Tafsir dengan Pendekatan Sufi." Wasathiyah 2, no. 1 (2018).

Marie, Farsat I. “موقف علماء أهل السنة من التأويل الباطني عند الاسماعيلية." Humanities Journal of University of Zakho 6, no. 3 (2018): 820-36.

Michaelis, Omer. "'Therefore I Have Removed the Veil': Disclosure of Secrets in Eleventh-Century Islam and the Literary Character of Maimonides's Guide." Harvard Theological Review 113, no. 3 (2020): 378-404.

Mohd Fuad, Mokhtar. "Ihsan Ilahi Zahir (1945-1987) Dan Kritikannya Terhadap Pemikiran Akidah Syiah/Mohd Fuad Mokhtar." University of Malaya, 2016.

Mohd Yusoff, Zulkifli, Samia Locate-Timol, Ismail Albayrak, Religious Studies, khairiah jamil, Muzaffar Muhammad Iqbal, Azhar Abdul Hafiz Hj Abdullah, et al. "Fi Munasabat Suwar Al-Quran Al-Karim." Journal of Qur'anic Studies 11, no. 1 (2015): 215. https://doi.org/10.22067/naqhs.v48i1.32876. 
Muaz, Abdul, and Tri Budi Prasetyo. "Mendaras Relasi Zikir Dan Jiwa." AnNufus 1, no. 1 (2019): 27-51.

Muhammad bin Ahmad al-Żahabī. Mĩzan Al-I’tidal. Riyāẹ: Shabkah Mishkāt alIslāmiyah, 1998.

Muhammad bin Jarīr al-Ṭabarī. Tarikh Al-Tabarì. Madīnah: Maktabah al-Ma'ārf li an-Nashr wa al-Tauzì', 1979.

Muhammad, Muștafā bin. Shubhatur Räfị̣ah Haula Al-Sabäbah. Beirut: Daar alKutub al-'Ilmiyyah (DKI) Publisher, 2000.

MUHAMMED, Qays Abdullah. “التفسير الإشاري بين الروعة والبدعة." Journal of Divinity Faculty of Hitit University 13, no. 25 (2014).

Mukhtār, As-Sayid. Manbaj Al-Tafsì Baina as-Sunnah Wa as-Shi ah Al-Imämiyah Al-Iśnà 'Ashariyah. Riyāẹ: Shabkah Mishkāt al-Islāmiyah, 1997.

Musā, Muhammad bin al-Husain bin. Nabjul Balägah. Qom, Iran: Markaz alAbhās̀ al-I'tiqādiyah, 2002.

Musolli, Musolli. "Ahlul Bayt Perspektif Syiah Dan Sunni: Studi Tafsir Al-Mizan Dan Tafsir Tahrir Wa Al-Tanwir." AT-TURAS: Jurnal Studi Keislaman 4, no. 1 (2017): 69-79.

Rizvi, Sajjad H. “'Only the Imam Knows Best' The Maktab-e Tafkik's Attack on the Legitimacy of Philosophy in Iran." Journal of the Royal Asiatic Society 22, no. 3-4 (2012): 487-503.

Setiadi, Ozi. "Faktor-Faktor Penyebab Penyimpangan dalam Tafsir." AlTadabbur: Jurnal Ilmu Al-Qur'an Dan Tafsir 3, no. 01 (2018).

Sulaiman, Sulaiman. "Tafsir Ilmi Dalam Persfektif Al-Qur'an." Al-Bayan: Jurnal Ilmu Al-Qur'an Dan Hadist 2, no. 2 (2019): 164-75.

Taimiyah, Ahmad bin Abdul Halīm bin. Minhäj Al-Sunnah Al-Nabawiyah. Cairo: Mu'assasah Qurțūbah, 1984.

Yakin, Syamsul. "Kritik Al-Ghazali Terhadap Aliran Bathiniyah Terkait Konflik Politik Sunni Dan Syiah Di Panggung Sejarah.” Refleksi 16, no. 1 (2017): 105-30.

Zāhir, Ihsān Ilahi. Al-Shìah Wa Al-Tashayyu'. Pakistan: Idārah Tarjūman alSunnah, 1984.

Zarghani, Muhammad, and Muhammad Hassan Nadem. "The Authority of the Shiite Imams'(AS) Tradition as the Qur'anic Interpreter and Its Relationship with the Authority of the Quran's Appearances." Asian Journal of Research in Social Sciences and Humanities 6, no. 6 (2016): 2381-93. 